\title{
Hafnium solubility determination in soda-lime aluminosilicate glass
}

\author{
P. Chevreux ${ }^{(a, b)}$, A. Laplace ${ }^{(a)}$, E. Deloule $^{(b)}$, L. Tissandier ${ }^{(b)}$, N. Massoni ${ }^{(a)}$
}

(a) CEA, DEN, DTCD, LDMC, Marcoule, F30207 Bagnols sur Cèze cedex, France

(b) Centre de Recherches Pétrographiques et Géochimiques, UMR 5873 CRNS, Université de Lorraine, BP 20, F54501, Vandoeuvre les Nancy cedex, France

\begin{abstract}
The solubility of hafnium dioxide $\left(\mathrm{HfO}_{2}\right)$, used as an uranium surrogate, is measured in glass melts belonging to the $\mathrm{CaO}-\mathrm{Al}_{2} \mathrm{O}_{3}-\mathrm{SiO}_{2}$ and $\mathrm{Na}_{2} \mathrm{O}-\mathrm{CaO}-\mathrm{Al}_{2} \mathrm{O}_{3}-\mathrm{SiO}_{2}$ systems, under oxidizing and reducing conditions. Two methods have been carried out to determine it and the kinetic factors controlling the $\mathrm{HfO}_{2}$ dissolution in glass melt have been investigated in order to approach equilibrium. The solubility ranges from 3 to $6.5 \mathrm{~mol} \% \mathrm{HfO}_{2}$ in aluminosilicate glasses at temperature between $1250^{\circ} \mathrm{C}$ and $1400^{\circ} \mathrm{C}$, and is not affected by the redox conditions. Conversely, the solubility is modified by the melting temperature and the glass composition. The excess of alkalies or alkaline earths which are not involved in the charge balance of $\mathrm{AlO}_{4}$ tetrahedrons in the silica network appears to play a significant role. Glass homogeneity is checked by scanning electron microscopy and X-ray diffraction. $\mathrm{HfO}_{2}$, $\mathrm{HfSiO}_{4}, \mathrm{Ca}_{2} \mathrm{HfSi}_{4} \mathrm{O}_{12}, \mathrm{Na}_{4} \mathrm{Hf}_{2}\left(\mathrm{SiO}_{4}\right)_{3}$ and $\mathrm{Na}_{2} \mathrm{HfSi}_{2} \mathrm{O}_{7}$ are metastable crystals observed in the glass melts. The stability of those crystalline phases mainly depends on the glass composition.
\end{abstract}

\section{Keywords}

Hafnium oxide, solubility, aluminosilicate glass melt, reducing conditions, crystallization.

\section{Introduction}

\subsection{Background}

Reprocessing of the spent nuclear fuel generates High Level Waste (HLW) which contains fission products and actinides. To be immobilized, these HLW are incorporated at about $1100^{\circ} \mathrm{C}$ in a borosilicate glass matrix. In the same way, Intermediate Level Waste (ILW) including both actinides and metals are planned to be confined by a vitrification process. The metallic fraction is melted with the glass melt at a higher temperature, between $1250^{\circ} \mathrm{C}$ and $1400^{\circ} \mathrm{C}$, and the glass melt is expected to incorporate the actinides, uranium and plutonium mainly, in its silicate network. As boron is known to volatilize from borosilicate melts at high temperature [1], aluminosilicate glasses appear as better candidates for that process. Besides, the molten metal phase imposes a strongly reducing environment to the glass melt and thus impacts actinides oxidation state and consequently their solubilities. In highly reducing conditions, $\mathrm{U}^{\mathrm{IV}}$ and $\mathrm{Pu}^{\mathrm{III}}$ are the main forms expected in the melt. Plutonium is more soluble in glass melted in reducing conditions (Pu'l') [2] while uranium is more soluble in oxidizing conditions $\left(\mathrm{U}^{\mathrm{V} /}\right)$ [3]. Moreover, only few data about uranium solubility in glasses melted in reducing conditions are given in the literature [3-7] and fundamental data on uranium behavior in aluminosilicate glasses have to be investigated in such conditions.

This study presents characteristics of aluminosilicate glasses containing hafnium $\left(\mathrm{Hf}^{\mathrm{IV}}\right)$ which is taken as uranium surrogate [8-11]. Uranium and hafnium are both heavy elements and display quite similar ionic radii for a given coordination number. Preliminary results with hafnium are shown here, before a further study with uranium. The first objective of this work is to study hafnium incorporation into a glass-forming melt under reducing environment and 
to optimize the Hf-doped glasses elaboration conditions in order to approach equilibrium. The second objective is to determine hafnium solubility as a function of the melting temperature, the glass composition and the redox conditions. Hafnium crystallization is also investigated.

\subsection{State of the art}

The thermodynamic solubility of an element in the glass is the maximum concentration of this element that can be loaded in the glass network at a given temperature. To determine it, two methods are commonly used. The first one consists in gradually increasing the amount the element to incorporate in the glass until a heterogeneous phase appears in the system (crystallization or/and demixing) [12]. The second one is embodied in introducing the desired element in excess in the glass and measuring its concentration in the vitreous matrix [13, 14]. That means the saturated glass melt shows lots of heterogeneities. To make a difference between the gradation and the saturation methods, we named the last one the saturation solubility $\left(S_{S}\right)$. The issue of reaching the equilibrium is raised in both cases. To approach equilibrium, the system has to verify several conditions [15], and if not, a conditional solubility $\left(\mathrm{S}_{\mathrm{C}}\right)$ can be introduced notably for the gradation method $[2,10]$. This solubility depends on the experimental conditions used by the authors and it may be lower than the thermodynamic solubility for the gradation method or higher for the saturation technique [16].

Most hafnium solubility studies are focused on borosilicate glasses. Lopez measured conditional solubilities in a borosilicate glass as function of the melting temperature [10]. At $1400^{\circ} \mathrm{C}$, hafnium conditional solubility was between 1.2 and $1.5 \mathrm{~mol} \% \mathrm{HfO}_{2}$. Cachia [17] reported a higher conditional solubility at the same temperature, between 1.8 and $2.2 \mathrm{~mol} \%$ $\mathrm{HfO}_{2}$ in the same glass by modifying the experimental protocol. In the $\mathrm{Na}_{2} \mathrm{O}-\mathrm{B}_{2} \mathrm{O}_{3}$ system, Res [18] observed that increasing the $\mathrm{Na}_{2} \mathrm{O}$ concentration improved the $\mathrm{HfO}_{2}$ solubility up to $12 \mathrm{~mol} \% \mathrm{HfO}_{2}$ at $1400^{\circ} \mathrm{C}$ for a glass containing $18 \mathrm{~mol} \% \mathrm{Na}_{2} \mathrm{O}$. Nevertheless, some dropletlike micro-heterogeneities were revealed by SEM in clear glasses. Feng [19] found that hafnium solubility in a sodium boro-aluminosilicate was positively related to the excess of $\mathrm{Na}_{2} \mathrm{O}$ relative to $\mathrm{Al}_{2} \mathrm{O}_{3}$. At $1450^{\circ} \mathrm{C}$, the highest solubility measured in a Na-rich glass was $14.4 \mathrm{~mol} \% \mathrm{HfO}_{2}$. Unfortunately, few data are given about the way of determining that solubility limit. The relationship between the hafnium solubility and glass composition was also investigated by Davis [8]. He demonstrated that the solubility limit of $\mathrm{HfO}_{2}$ in peralkaline glasses $\left(\mathrm{Na}_{2} \mathrm{O}\right.$ mol\% $>\mathrm{Al}_{2} \mathrm{O}_{3}$ mol\%) in the system $\mathrm{SiO}_{2}-\mathrm{Al}_{2} \mathrm{O}_{3}-\mathrm{B}_{2} \mathrm{O}_{3}-\mathrm{Na}_{2} \mathrm{O}$ was linearly and positively correlated with the molar $\mathrm{Na}_{2} \mathrm{O} /\left(\mathrm{Na}_{2} \mathrm{O}+\mathrm{Al}_{2} \mathrm{O}_{3}\right)$ ratio. The solubility of $\mathrm{HfO}_{2}$ in these glasses ranged from 2 to $16 \mathrm{~mol} \%$ at $1450^{\circ} \mathrm{C}$. This "peralkalinity effect" had been alike observed in B-free glass melts for +4 cations (such as $\mathrm{Zr}^{\mathrm{IV}}$ and $\mathrm{Ti}^{\mathrm{IV}}$ ) $[14,15,20]$. In contrast, the mechanism for $\mathrm{HfO}_{2}$ dissolution seems to be different in peraluminous glasses $\left(\mathrm{Na}_{2} \mathrm{O}\right.$ mol\% $<\mathrm{Al}_{2} \mathrm{O}_{3}$ mol\%). In the peraluminous melts, the $\mathrm{HfO}_{2}$ measured solubility by Davis [8] is lower than $3 \mathrm{~mol} \%$ and, $\mathrm{B}_{2} \mathrm{O}_{3}$ and $\mathrm{Al}_{2} \mathrm{O}_{3}$ may help to solubilize it. Ellison [20] showed that hafnium solubility decreased in $\mathrm{B}$-free peraluminous melts in the system $\mathrm{SiO}_{2}-\mathrm{Al}_{2} \mathrm{O}_{3}-\mathrm{Na}_{2} \mathrm{O}-$ $\mathrm{K}_{2} \mathrm{O}$ with the $\mathrm{SiO}_{2}$ content increasing and measured solubility limits lower than $1 \mathrm{~mol} \% \mathrm{HfO}_{2}$ in equilibrated liquids at $1400^{\circ} \mathrm{C}$. Above the solubility limit, the Hf-bearing crystallized phases were mainly monoclinic hafnia $\left(\mathrm{HfO}_{2}\right)[8,9,18]$ and occasionally hafnon $\left(\mathrm{HfSiO}_{4}\right)[10,20]$. All these authors had melted their glasses under oxidizing conditions, namely in air and in Pt$\mathrm{Rh}, \mathrm{ZrO}_{2}$ or $\mathrm{Al}_{2} \mathrm{O}_{3}$ crucibles. 


\section{Experimental and analytical procedures}

\subsection{General features}

$\mathrm{Hf}$ solubility was determined in two simplified aluminosilicate glasses based on the industrial glass formulation $A$ and $B, A$ glass containing 22.33 mol\% $\mathrm{Na}_{2} \mathrm{O}$ while $\mathrm{B}$ being sodium free (Table 1) and for two bracketing temperatures $\left(1250^{\circ} \mathrm{C}\right.$ and $\left.1400^{\circ} \mathrm{C}\right)$. Redox conditions during the Hf-doped glasses meting were changed using different types of crucibles and atmospheres. Platinum crucible (Pt-5\%Au) and air atmosphere were used for oxidizing conditions, while pure graphite $\left(\mathrm{C}_{g}\right)$ or graphite and silicon carbide (C-SiC) crucibles and argon ( $\mathrm{Ar}$ ) atmosphere imposed reducing conditions. The C-SiC crucible (A5/0 Salamander Super, Morgan MMS) is a type of crucible frequently used in the metallurgy field. It is mainly composed of $\mathrm{C}_{\mathrm{g}}$, $\mathrm{SiC}$, a mullite binder $\left(3 \mathrm{Al}_{2} \mathrm{O}_{3}-2 \mathrm{SiO}_{2}\right)$ and some impurities such as $\mathrm{Fe}_{3} \mathrm{Si}$. $\mathrm{Ar}$ atmosphere was used to prevent these crucibles from corrosion.

\subsection{Glass fabrication}

\subsubsection{Starting glasses}

The $\mathrm{A}$ and $\mathrm{B}$ glasses (Table 1) were prepared with the following commercial precursors: $\mathrm{SiO}_{2}$ (Sifraco, 0.994); $\mathrm{Na}_{2} \mathrm{CO}_{3}$ (Sigma-Aldrich, 1); $\mathrm{CaO}$ (Aldrich, 0.999); $\mathrm{Al}_{2} \mathrm{O}_{3}$ (Sigma-Aldrich, 1). For the Na-rich A glass, a decarbonation step was previously performed at $850^{\circ} \mathrm{C}$ for $6 \mathrm{~h}$. Then, the mixed components $(\approx 150 \mathrm{~g})$ were melted at $1400^{\circ} \mathrm{C}$ for $3 \mathrm{~h}$ in a platinum crucible (Pt-10\%Rh), under air. Glass melts were then poured in stainless steel plate, milled and screened up to $400 \mu \mathrm{m}$ particle size to be further used as starting glass materials for $\mathrm{Hf}$ doped glasses. Milling was performed in a tungsten carbide (WC) vessel using WC balls (Planetary Ball Mill PM 200).

Hafnium was added as $\mathrm{HfO}_{2}$ powder (Alfa Aesar, 0.999) and mixed with the former glass powders. Three different types of hafnium particle size were used: 15, 70 and $158 \mu \mathrm{m}$.

The particle size, expressed as the median value $\left(d_{50}\right)$ and size distribution of powders were determined from the volume distribution measured by a laser granulometer (Malvern Mastersizer 3000) in ethanol.

$\mathrm{C}$ glass was formed by adding $1.56 \mathrm{~mol} \% \mathrm{HfO}_{2}$ to the Na-rich glass (Table 1). This value of $1.56 \mathrm{~mol} \% \mathrm{HfO}_{2}$ is a relevant content for the industrial process. Moreover, the hafnium solubility in glass melt should be higher than this value as referenced in paragraph 1.2.

Table 1

Targeted chemical compositions of main glasses.

Glass composition (mol\%)

\begin{tabular}{cccccc} 
Sample name & $\mathrm{SiO}_{2}$ & $\mathrm{Al}_{2} \mathrm{O}_{3}$ & $\mathrm{CaO}$ & $\mathrm{Na}_{2} \mathrm{O}$ & $\mathrm{HfO}_{2}$ \\
\cline { 2 - 6 } $\mathrm{A}$ & 57.43 & 6.25 & 13,99 & 22.33 & 0 \\
$\mathrm{~B}$ & 57.43 & 6.25 & 36.32 & 0 & 0 \\
C & 56.54 & 6.15 & 13.77 & 21.98 & 1.56 \\
\hline
\end{tabular}




\subsubsection{Optimized protocol definition for Hf-doped glasses}

The influence of different experimental parameters $\left(\mathrm{HfO}_{2}\right.$ particle size, fusions number, melting time and temperature) has been checked for the $\mathrm{C}$ glass elaboration in order to optimize the process (Table 2$)$. The powder mixture $(\approx 3 \mathrm{~g})$ was melted in a C-SiC crucible under Ar atmosphere. After melting, the molten glass was cooled by shutting off the heat source (cooling rate $<8^{\circ} \mathrm{C} / \mathrm{min}$ ). In case of several meltings, each remelting was preceded by a glass sample milling step (WC vessel and ball, Mixer Mill MM 200) to ensure its homogenization. Final glass samples were removed from the crucible and have roughly a 20 $\mathrm{mm}$ diameter and $6 \mathrm{~mm}$ height (Figure 2). An optimized protocol was then defined for $\mathrm{Hf}$ solubility measurements. To minimize hafnium sedimentation and its heterogeneities, fine $\mathrm{HfO}_{2}$ powders were used (15 $\mu \mathrm{m}$ particle size). Remeltings enabled to homogenize the whole glass melt. The $3 \mathrm{~h}$ run duration allowed to avoid bubbles and longer run duration did not really impact the $\mathrm{HfO}_{2}$ dissolution and had the drawback of increasing the $\mathrm{Na}$ volatilization. Thus, the experimental procedure followed for solubility measurements comprised three meltings for $3 \mathrm{~h}$ at $1250^{\circ} \mathrm{C}$ or $1400^{\circ} \mathrm{C}$ with two intermediate glass millings (Figure 1).

Table 2

Glass elaboration parameters of $1.56 \mathrm{~mol} \% \mathrm{HfO}_{2}$-doped glasses melted in C-SiC crucible.

Glass elaboration parameters

\begin{tabular}{ccccc} 
Sample name & Melting time & $\begin{array}{c}\text { Melting } \\
\text { temperature }\end{array}$ & $\begin{array}{c}\mathrm{HfO}_{2} \text { particle } \\
\text { size }\end{array}$ & $\begin{array}{c}\text { Fusions } \\
\text { number }\end{array}$ \\
\cline { 2 - 5 } $\mathrm{C} 0$ & $3 \mathrm{~h}$ & $1250^{\circ} \mathrm{C}$ & $70 \mu \mathrm{m}$ & 1 \\
$\mathrm{C} 1$ & $12 \mathrm{~h}$ & $1250^{\circ} \mathrm{C}$ & $70 \mu \mathrm{m}$ & 1 \\
$\mathrm{C} 2$ & $3 \mathrm{~h}$ & $1400^{\circ} \mathrm{C}$ & $70 \mu \mathrm{m}$ & 1 \\
$\mathrm{C} 3$ & $3 \mathrm{~h}$ & $1250^{\circ} \mathrm{C}$ & $158 \mu \mathrm{m}$ & 1 \\
$\mathrm{C} 4$ & $3 \mathrm{~h}$ & $1250^{\circ} \mathrm{C}$ & $15 \mu \mathrm{m}$ & 1 \\
$\mathrm{C} 5$ & $3 \mathrm{~h}+3 \mathrm{~h}$ & $1250^{\circ} \mathrm{C}$ & $70 \mu \mathrm{m}$ & 2 \\
$\mathrm{C} 6$ & $3 \mathrm{~h}+3 \mathrm{~h}+1 \mathrm{~h}$ & $1250^{\circ} \mathrm{C}$ & $70 \mu \mathrm{m}$ & 3 \\
\hline
\end{tabular}

$A$ and $\mathrm{B}$ glass powders were respectively mixed with different amounts of $\mathrm{HfO}_{2}$, ranging from $1.56 \mathrm{~mol} \%$ to $10 \mathrm{~mol} \% \mathrm{HfO}_{2}$ in the final glass. The powder mixture was fused either in a Pt$\mathrm{Au}$ crucible and air atmosphere (oxidizing conditions) or in a C-SiC (or $\mathrm{C}_{\mathrm{g}}$ ) crucible under $\mathrm{Ar}$ atmosphere (reducing conditions). Glasses were directly quenched in air (cooling rate about $100^{\circ} \mathrm{C} / \mathrm{min}$ ) and then milled. The milling and remelting steps were done twice. Finally, the crucible was removed from the hot furnace and quenched immediately by immersing the bottom of the crucible into a cold water bath to prevent crystallization during cooling (cooling rate about $\left.100^{\circ} \mathrm{C} / \mathrm{s}\right)$. Glasses were not annealed. 


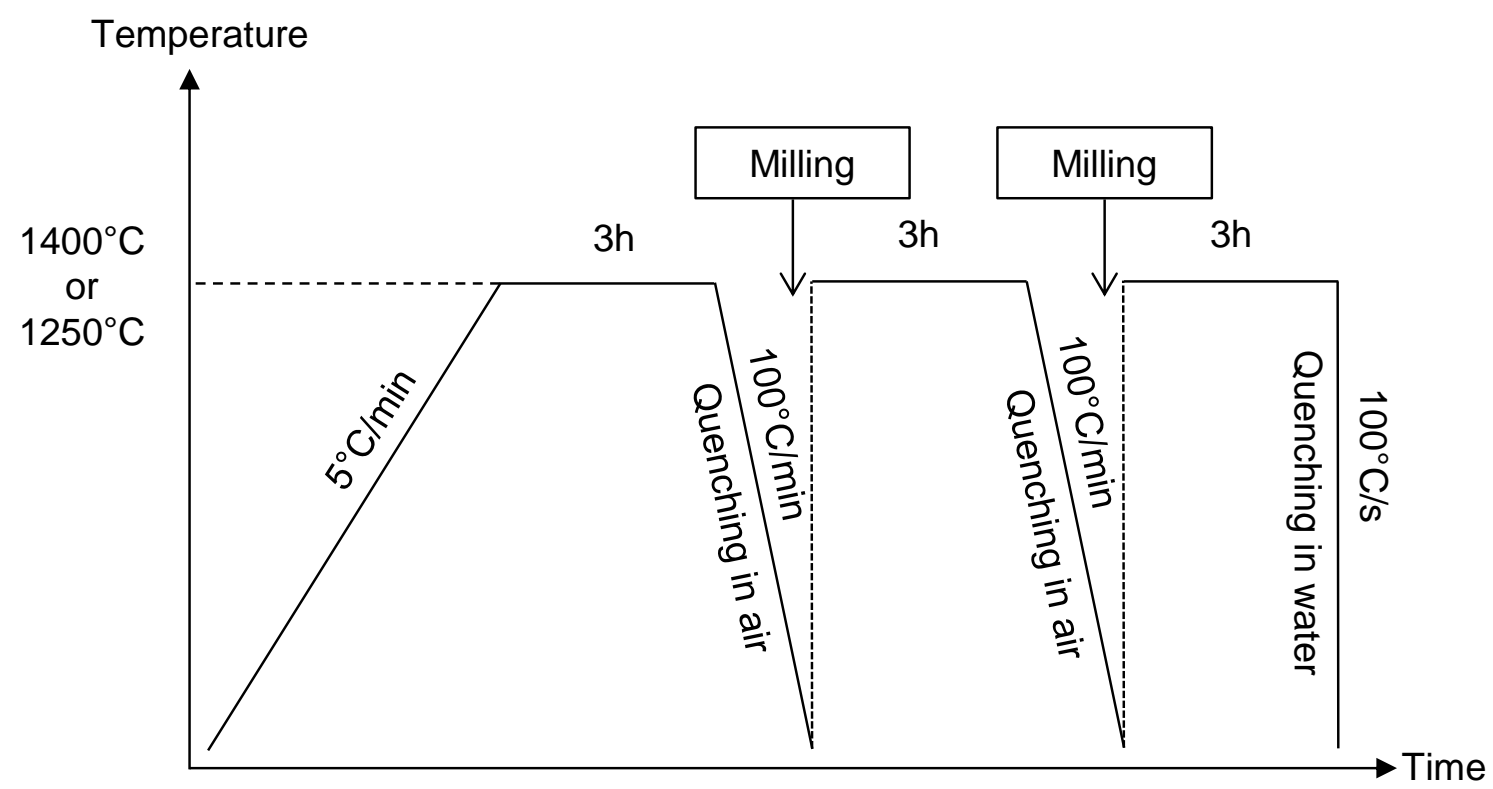

Figure 1. The general procedure of glass elaboration for Hf solubility measurements.

\subsection{Glass characterizations}

\subsubsection{Homogeneity}

Glass sample homogeneity was determined by scanning electron microscopy (SEM) and Xray diffraction (XRD). Secondary phases morphology and size were observed by SEM (Phillips XL30-WTMP and ZEISS Supra 55 FEG) coupled with energy dispersive X-ray spectroscopy (Brucker EDS analyser) allowing glass composition semi-quantitative analysis. The conditions for electron microprobe analysis were an acceleration voltage $15 \mathrm{keV}$, a total of $5.10^{5}$ counts and a Phirho(Z) method with standards. For SEM observations, crucibleshaped glass samples were cut in the middle and mounted in epoxy resin before being polished and carbon coated. Crystalline phases were identified by a PANalytical diffractometer (X'Pert MPD Pro, Bragg-Bretano geometry using a Ni-filtered the Cu Ka radiation, solid detector $X^{\prime}$ Celerator) using the EVA software from Bruker AXS company. The data acquisition was completed in the step scan mode $\left(10-90^{\circ} 2 \theta\right.$, step size $0,017^{\circ} 2 \theta$, total time counting of at least $5 \mathrm{~h}$ ). XRD measurements were carried out on glass powders. The modelization of the X-ray pattern was performed in two steps using the Fullprof_Suite program [21]. Lattice parameters were first determined by the whole pattern decomposition then the structure was modeled by the Rietveld technique. Rietveld refinement was realized for highly crystallized glasses to assess the phases inventory previously done and obtain the relative mass fraction of each crystalline phase. For the latter, the amorphous phase is not considered.

\subsubsection{Properties}

The glass density was measured using a hydrostatic balance; the glass was weighed in air and then, in water according to Archimedes' principle. The reported density represents the mean value of three measurements.

Viscosity measurements were performed by a stress imposed rheometer (Rheometrics Scientific SR 5000) [22]. Basically, the rheometer was located above a vertical tubular furnace and a cylindrical crucible was placed in the furnace center. Rheological measurements were realized with a cylindrical rotor in the Couette geometry. Measurements 
were performed at several temperatures. For Newtonian melts, a model following a VogelFulcher-Tammann (VFT) law was applied [23].

\section{Results}

\subsection{Hafnium incorporation}

\subsubsection{Sedimentation and heterogeneities}

The $\mathrm{C} 3$ glass sample containing $1.56 \mathrm{~mol} \% \mathrm{HfO}_{2}(158 \mu \mathrm{m}$ particle size) and elaborated for 3 hours at $1250^{\circ} \mathrm{C}$ is firstly observed. The glass is transparent with a slightly yellowish tint, probably, due to minor contamination from the crucible or the grinding vessel (Figure 2) [8]. Hafnia sedimentation is clearly observed at the bottom (Figure 2a) and the sample displays two distinct parts. In the top half, glass seems to be homogeneous without any crystalline phases, which is confirmed by SEM images (Figure 2b). Few bubbles are noticed. Heterogeneities, composed of crystal clusters, are only detected at the bottom (Figure $2 b$ ). According to XRD patterns, the crystalline phases are monoclinic $\mathrm{HfO}_{2}$, hexagonal $\mathrm{Na}_{4} \mathrm{Hf}_{2}\left(\mathrm{SiO}_{4}\right)_{3}$ and triclinic $\mathrm{Na}_{2} \mathrm{ZrSi}_{2} \mathrm{O}_{7}$ (more details in paragraph 3.2.2). Graphite $\mathrm{C}_{g}$ is also detected by XRD. Hafnium being a heavy element, it is easily observable using back scattered electrons (BSE). In the analyzed section, $\mathrm{Na}_{4} \mathrm{Hf}_{2}\left(\mathrm{SiO}_{4}\right)_{3}$ and $\mathrm{HfO}_{2}$ crystals are identified by SEM (Figure 2c) contrary to the crystalline phase $\mathrm{Na}_{2} \mathrm{ZrSi}_{2} \mathrm{O}_{7}$. White halos surrounding theses crystals are also observed in BSE (Figure 2b), which demonstrates hafnium enrichment in the vitreous matrix. An hafnium concentration gradient in the glass matrix is observed in the whole sample, a lower concentration at the top and in the middle of sample (between 0.3 and $0.4 \mathrm{~mol} \% \mathrm{HfO}_{2}$ ) than at the bottom $\left(1.3 \mathrm{~mol} \% \mathrm{HfO}_{2}\right)($ Figure 3a). 

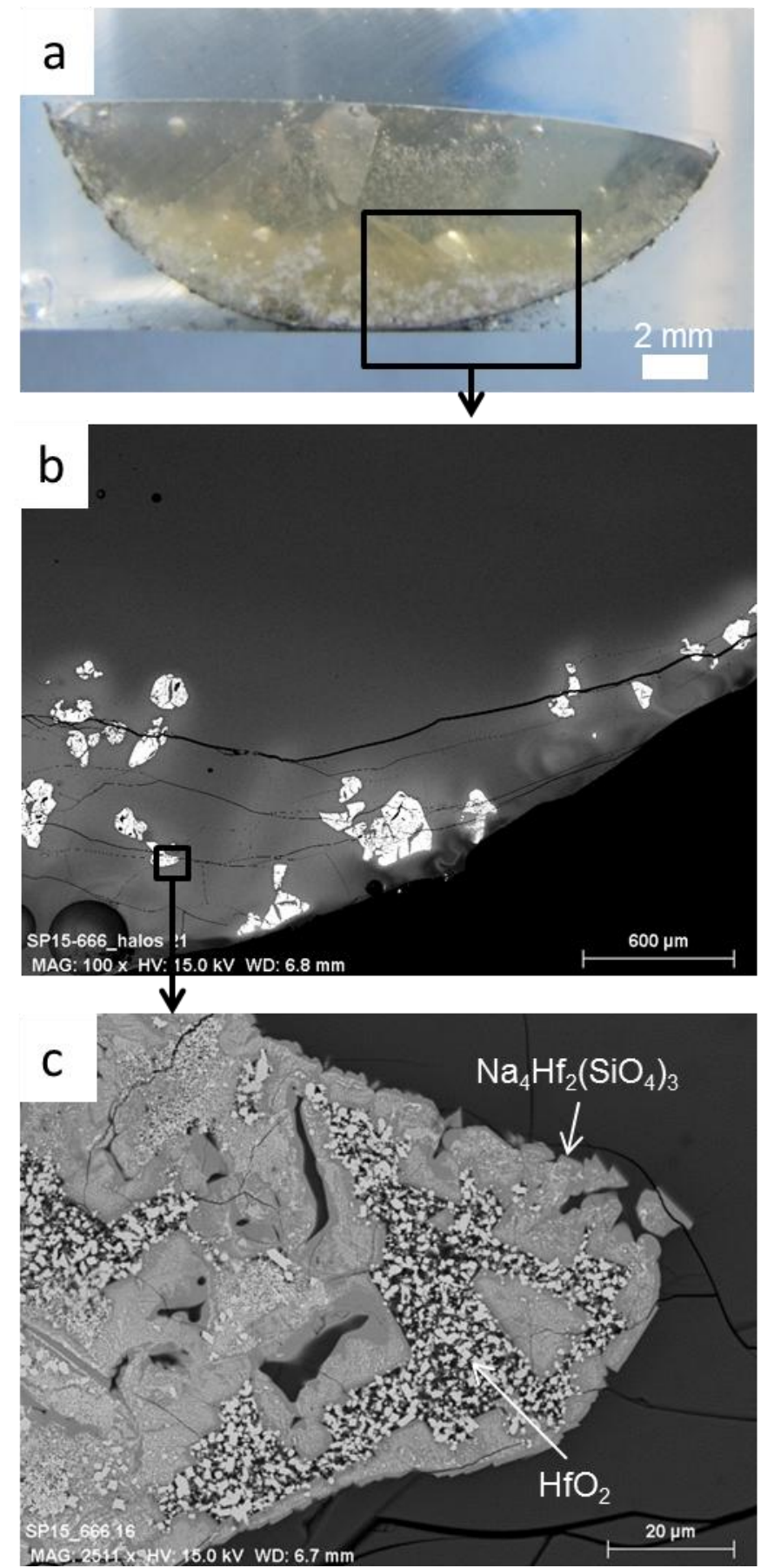

Figure 2. Picture (a) and scanning electron microscopy images (b) and (c) of heterogeneities observed in Hfdoped glass (C3 sample).

To avoid these heterogeneities, several parameters were investigated such as hafnium precursor particle size, run duration, meltings number and temperature (Table 1). The glass sample microstructure was observed by SEM (Figure 4) and the $\mathrm{HfO}_{2}$ concentration in glass network was determined by EDS analysis in three specific glass areas and compared to the targeted value, 1.56 mol\% $\mathrm{HfO}_{2}$ (Figure 3). The absence of $\mathrm{HfO}_{2}$ compositional gradients in the glass was one of the features consistent with an approach to equilibrium. 


\subsubsection{Effect of precursor particle size}

$\mathrm{C} 0, \mathrm{C} 3$ and C4 glass samples followed identical thermal treatment $\left(1250^{\circ} \mathrm{C}, 3 \mathrm{~h}\right)$ but were prepared with different hafnium powder particle sizes, namely and respectively 158, 70 and $15 \mu \mathrm{m}$. The decrease of the $\mathrm{HfO}_{2}$ particle size widely limits the $\mathrm{HfO}_{2}$ sedimentation by decreasing the amount and size of hafnium crystals in the glass (Figure $4 a, b$ and $c$ ). The size of agglomerated crystals is from 200 to $400 \mu \mathrm{m}$ sized in the C3 glass compared to 50$100 \mu \mathrm{m}$ in the C0 glass. In the C4 glass, where hafnium particle size is very fine $(15 \mu \mathrm{m})$, only a few of those crystals are noticed. Moreover, reactivity between glass and hafnium powders is enhanced using fine powders (increase of the reactive surface for a given volume). As a consequence, hafnium concentration in the glass melt is largely increased and almost reaches the targeted value (Figure 3a). However, a concentration gradient still remains in the whole sample. In the next parts, the intermediate $70 \mu \mathrm{m}$ particle size (C0 glass) is selected to study the effect of the other parameters.

\subsubsection{Effect of melting time}

$\mathrm{C} 0$ and $\mathrm{C} 1$ glasses were elaborated at $1250^{\circ} \mathrm{C}$ for, respectively $3 \mathrm{~h}$ and $12 \mathrm{~h}$. Increasing melting time does not change the samples general feature. White halos, hafnium concentration gradient and hafnium crystals at the bottom were still identified in the $\mathrm{C} 1$ glass (Figure $3 \mathrm{~b}$ and Figure $4 \mathrm{~d}$ ). Nevertheless, hafnium concentration is higher at the bottom and the middle in the $\mathrm{C} 1$ glass than in the $\mathrm{C} 0$ one (about $40-50 \%$ more). On top of the sample, the hafnium concentration remains the same.

\subsubsection{Effect of remelting}

To achieve good homogenization, glasses are usually milled and melted several times $[9,11$, 20]. A standard remelting procedure was introduced with an intermediate milling step. Glass samples were melted once (C0 glass), twice (C5 glass) or three times (C6 glass) at $1250^{\circ} \mathrm{C}$ (Table 2). The hafnium concentration gradient has almost vanished after the second melting (Figure 3c). Hafnium concentration in the C5 glass is very close to the targeted value. Nevertheless, few hafnium crystals still stay at the bottom. After the third melting, C6 glass is homogeneous in concentration and only one hafnium crystal is found in the whole sample (Figure 4f). Bubbles are observed in both C5 and C6 glasses because of introduced air by the milling step. The milling step appears to be essential to homogenize the glass. This method (successive milling and remelting steps) is a convenient way of "stirring" the melt, and thus of improving dissolution kinetics, when thermal treatments can only be realized under static conditions $[6,24]$.

\subsubsection{Effect of melting temperature}

The impact of the melting temperature was briefly studied. Indeed, some authors managed to get equilibrated melts by increasing the temperature up to $1560^{\circ} \mathrm{C}$ [8]. In this study, the melting temperature was limited to $1400^{\circ} \mathrm{C}$ to minimize Na volatilization. A C2 glass sample was synthetized at $1400^{\circ} \mathrm{C}$ for $3 \mathrm{~h}$. Figure $3 \mathrm{~d}$ shows that temperature increasing improves hafnium solubilization in the whole glass. Nonetheless, hafnium concentration gradient is also emphasized. At the bottom, a thick and whiter Hf-rich layer, about $0.65-1 \mathrm{~mm}$ (versus the $6 \mathrm{~mm}$ glass height) is observed (Figure 4e). This layer contains $\mathrm{HfO}_{2}$ crystals and the surrounding $\mathrm{Hf}$ concentration is estimated up to $7.5 \% \mathrm{~mol} \mathrm{HfO}_{2}$ in the melt. Above that layer, the $\mathrm{Hf}$ concentration is below $1.56 \mathrm{~mol} \%$. The crystalline phase $\mathrm{Na}_{4} \mathrm{Hf}_{2}\left(\mathrm{SiO}_{4}\right)_{3}$ seems to be entirely dissolved in the glass at $1400^{\circ} \mathrm{C}$ as a reaction intermediate.

As expected, the C-SiC crucible provides a strong reducing environment and is able to reduce part of $\mathrm{Na}_{2} \mathrm{O}$ to the metallic form $\mathrm{Na}^{0}$ at high temperature [25]. In these experiments, 
the glass lost, respectively, $14 \%$ and $28 \%$ of $\mathrm{Na}_{2} \mathrm{O}$ after $3 \mathrm{~h}$ and $12 \mathrm{~h}$ at $1250^{\circ} \mathrm{C}$. The $\mathrm{Na}$ loss was around $37 \%$ after two meltings of $3 \mathrm{~h}$ at $1250^{\circ} \mathrm{C}$ and $38 \%$ after $3 \mathrm{~h}$ at $1400^{\circ} \mathrm{C}$.

These first experiments enabled to define an optimized $\mathrm{Hf}$-doped glass elaboration procedure (Figure 1) allowing to approach the equilibrium and thus to measure solubility limits, while limiting the compositional changes due to alkali loss.
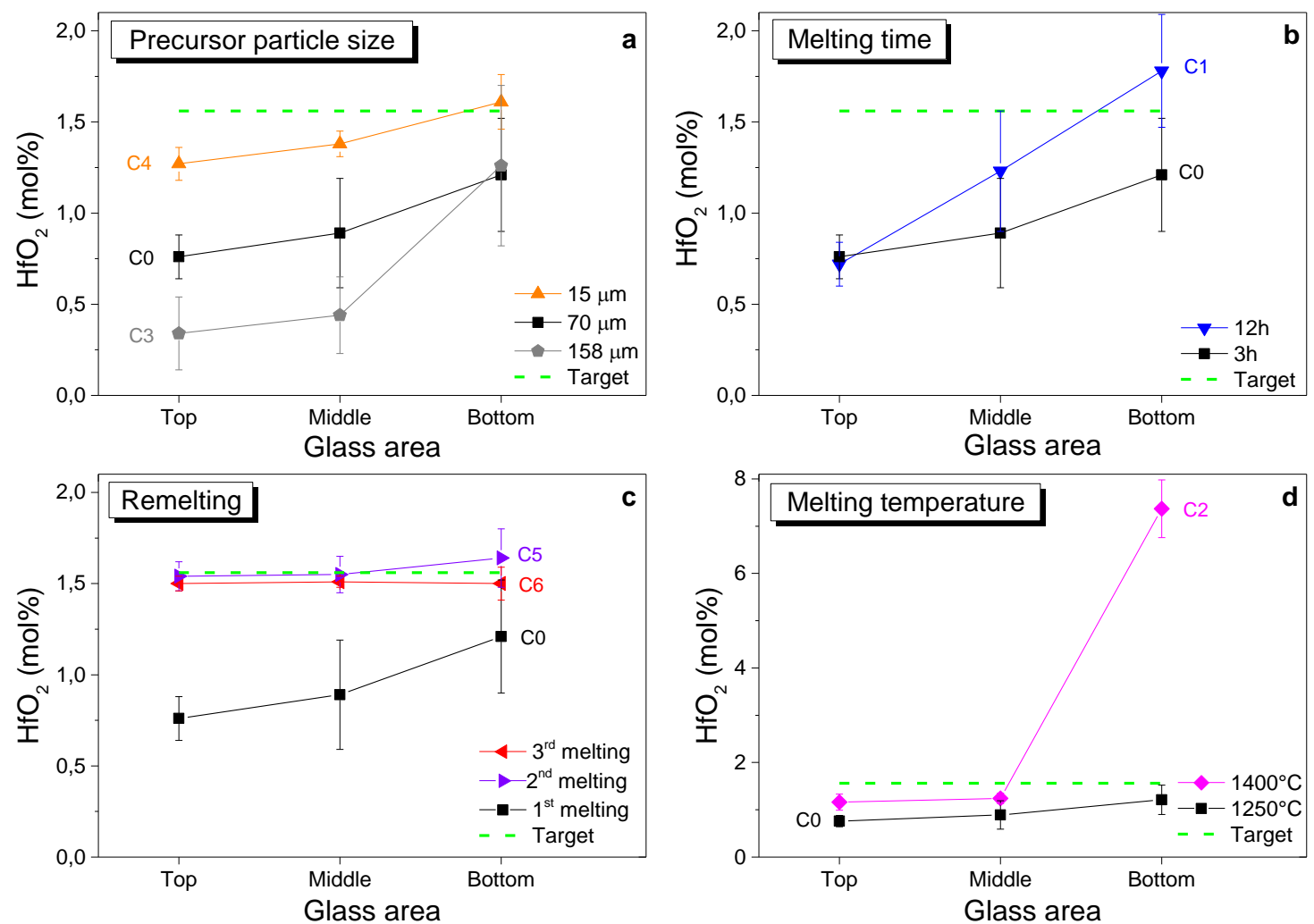

Figure 3. Variation in $\mathrm{HfO}_{2}$ concentration as a function of glass area for several glasses elaborated in different conditions. Impact of (a) $\mathrm{HfO}_{2}$ particle size, (b) melting time, (c) remelting, (d) melting temperature. $\mathrm{HfO}_{2}$ concentration as related to mole percent. Error bars represent the random standard uncertainty calculated by multiplying the standard deviation of the mean and the student t-factor at the $95 \%$ level of confidence. 

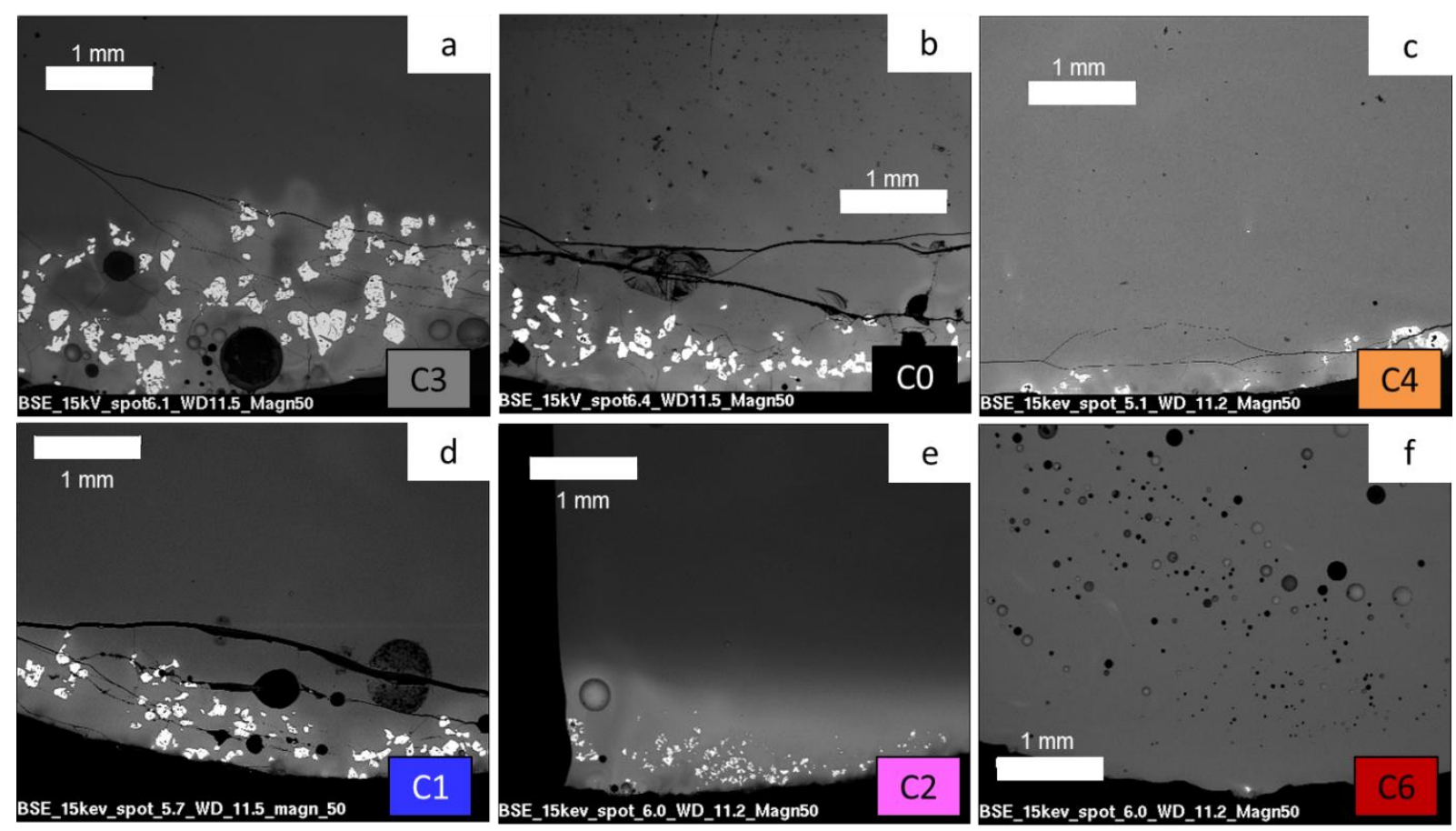

Figure 4. SEM images of $\mathrm{Hf}$-doped glasses melted in different conditions: effect of $(a, b, c)$ particle size, (b,d) melting time, $(b, e)$ melting temperature, and $(b, f)$ remelting. The name of observed glasses is given at the bottom right corner.

\subsection{Solubility study}

\subsubsection{Hafnium solubility}

The $\mathrm{HfO}_{2}$ solubility in the aluminosilicate glass was determined in oxidizing (Pt-Au crucible) and reducing (C-SiC or $\mathrm{C}_{g}$ crucibles) conditions at $1250^{\circ} \mathrm{C}$ and $1400^{\circ} \mathrm{C}$ for $\mathrm{A}$ glasses and only at $1400^{\circ} \mathrm{C}$ for $\mathrm{B}$ glasses, because below $1327^{\circ} \mathrm{C}$, B melt starts to crystallize. Both conditional $\left(\mathrm{S}_{\mathrm{C}}\right)$ and saturation $\left(\mathrm{S}_{\mathrm{S}}\right)$ solubilities were measured and are indicated in Table 3. The $\mathrm{S}_{\mathrm{C}}$ is determined by progressively increasing the amount of added $\mathrm{HfO}_{2}$ in the glass until the formation of $\mathrm{Hf}$-bearing crystals (Figure $5 \mathrm{a}$ and b). The lower limit corresponds to the maximal quantity of $\mathrm{Hf}$ that could be incorporated in the homogeneous glass matrix. And the upper limit refers to the quantity of $\mathrm{Hf}$ where the first heterogeneities are observed. The $\mathrm{S}_{\mathrm{S}}$ is characterized by $\mathrm{HfO}_{2}$ concentration measurements in a $\mathrm{HfO}_{2}$-saturated glass with $\mathrm{Hf}$-bearing crystals (Figure $5 \mathrm{c}$ and d). The main glasses compositions are shown in Table 4. Each Hf concentration value represents an average of several measurements (from 6 to 12 points of EDS analyses). 


\section{Gradation}

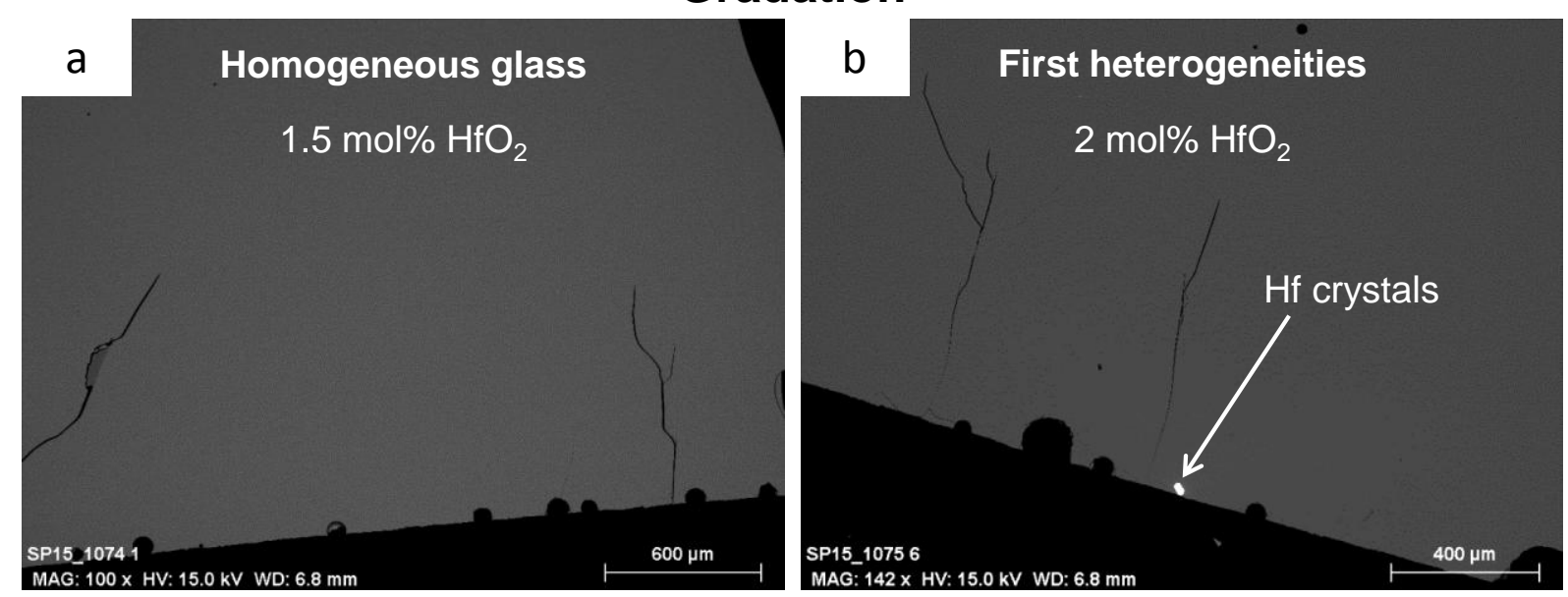

\section{Saturation}

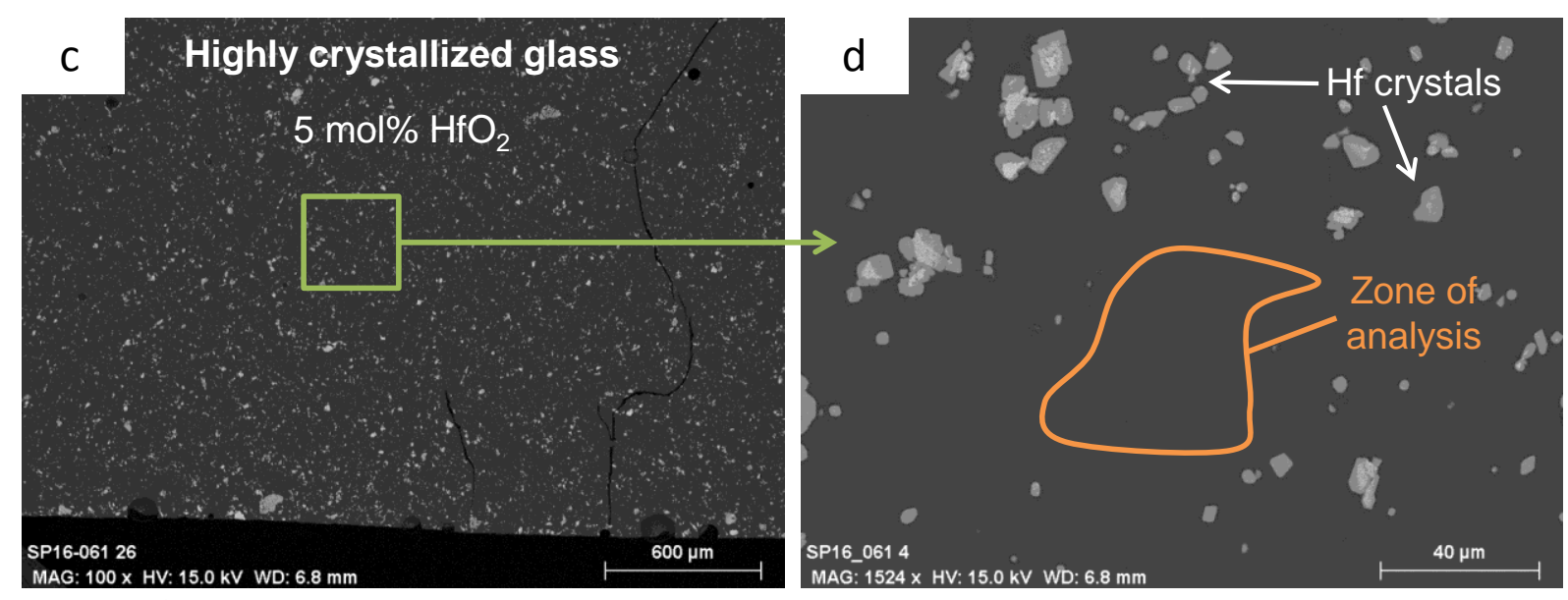

Figure 5. SEM images of $\mathrm{Hf}$-doped A glasses, elaborated in Pt-Au crucible at $1250^{\circ} \mathrm{C}$, containing (a) $1.5 \mathrm{~mol} \%$, (b) $2 \mathrm{~mol} \%$ and $(\mathrm{c}, \mathrm{d}) 5 \mathrm{~mol} \% \mathrm{HfO}_{2}$, showing the two methods for the solubility measurements (gradation and saturation). 


\section{Table 3}

Solubility limits of hafnium determined in $\mathrm{A}$ and $\mathrm{B}$ aluminosilicate glasses elaborated in oxidizing and reducing conditions at $1250^{\circ} \mathrm{C}$ and $1400^{\circ} \mathrm{C}$.

\begin{tabular}{|c|c|c|c|c|c|}
\hline \multirow{2}{*}{$\begin{array}{c}\text { Hf-doped } \\
\text { glasses } \\
\text { Glass } \\
\text { series }\end{array}$} & \multicolumn{3}{|c|}{ Melting conditions } & \multicolumn{2}{|c|}{ Hafnium solubility limits } \\
\hline & $\begin{array}{c}\mathrm{T} \\
\left({ }^{\circ} \mathrm{C}\right)\end{array}$ & Crucible & Atmosphere & $\begin{array}{l}\text { Conditional solubility } \\
\left(\mathrm{HfO}_{2} \mathrm{~mol} \%\right)\end{array}$ & $\begin{array}{l}\text { Saturation solubility } \\
\left(\mathrm{HfO}_{2} \mathrm{~mol} \%\right)\end{array}$ \\
\hline \multirow{4}{*}{ A-series } & 1250 & Pt-Au & Air & $1.5^{\mathrm{a}}<\mathrm{S}_{\mathrm{c}}<2^{\mathrm{c}}$ & 3 \\
\hline & 1250 & $\mathrm{C}-\mathrm{SiC}$ & Air - Ar & $2.5^{\mathrm{a}}<\mathrm{S}_{\mathrm{c}}<3^{\mathrm{c}}$ & l \\
\hline & 1400 & Pt-Au & Air & $5^{\mathrm{a}}<\mathrm{S}_{\mathrm{c}}<7^{\mathrm{c}}$ & $6-6.5$ \\
\hline & 1400 & $\mathrm{C}-\mathrm{SiC}$ & Air - Ar & $3^{b}<S_{c}<5^{c}$ & 4.5 \\
\hline \multirow{3}{*}{ B-series } & 1400 & Pt-Au & Air & $3^{a}<S_{c}<4^{c}$ & $5.5-6$ \\
\hline & 1400 & C-SiC & Air - Ar & $3.5^{\mathrm{a}}<\mathrm{S}_{\mathrm{c}}<4^{\mathrm{c}}$ & $3.5-4$ \\
\hline & 1400 & $\mathrm{C}_{\mathrm{g}}$ & Air-Ar & I & 6 \\
\hline $\begin{array}{l}{ }^{\mathrm{a}} \text { Homoge } \\
\text { b }{ }^{\mathrm{C}} \text { Glass co } \\
{ }^{\mathrm{c}} \text { Glass co }\end{array}$ & $\begin{array}{l}\text { us gl } \\
\text { ning } \\
\text { ning }\end{array}$ & $\begin{array}{l}\text { dritic crys } \\
\text { tals }\end{array}$ & & & \\
\hline
\end{tabular}

The measured conditional solubility is either lower or close to the saturation solubility. The $\mathrm{S}_{S}$ limit is higher than the upper $\mathrm{S}_{\mathrm{C}}$ limit only for two Hf-bearing glasses: $\mathrm{A}$ and $\mathrm{B}$ glasses melted in a Pt-Au crucible at $1250^{\circ} \mathrm{C}$ and $1400^{\circ} \mathrm{C}$ respectively. This suggests that the glass elaboration conditions were well-optimized to reach equilibrium for most glasses. However, the saturation solubility is independent of hafnium dissolution kinetics contrary to the conditional solubility. In the nuclear field, the conditional solubility has been used to compare actinides and surrogates [10,12]. This solubility ensures that the glass sample is totally homogeneous for a given glass-making protocol but does not necessarily correspond to the maximum amount that can be incorporated in the glass. In the following, we will essentially consider the saturation solubility. Indeed, we can consider that saturation experiments provide us hafnium concentrations close to the equilibrium concentration, as no hafnium concentration gradient is observed. Only the A glass with $10 \mathrm{~mol} \% \mathrm{HfO}_{2}$ melted in $\mathrm{C}-\mathrm{SiC}$ crucible at $1250^{\circ} \mathrm{C}$ (AS8 sample) showed a concentration gradient, and consequently, the $\mathrm{HfO}_{2}$ saturation solubility limit was not determined for it. Furthermore, an excess of hafnium above the saturation solubility should not significantly change the saturation concentration of $\mathrm{HfO}_{2}$. 
The redox conditions (oxidizing or reducing conditions) do not affect the hafnium solubility. Saturation experiments in $\mathrm{C}_{\mathrm{g}}$ and $\mathrm{Pt}-\mathrm{Au}$ crucibles for the B-series show that BS4 and BS5 glasses exhibit the same saturation concentration about $5.5-6 \mathrm{~mol} \% \mathrm{HfO}_{2}$ at $1400^{\circ} \mathrm{C}$.

The hafnium concentration of $\mathrm{HfO}_{2}$-saturated melts increases with the melting temperature, from $3 \mathrm{~mol} \% \mathrm{HfO}_{2}$ at $1250^{\circ} \mathrm{C}$ to $6-6.5 \mathrm{~mol} \% \mathrm{HfO}_{2}$ at $1400^{\circ} \mathrm{C}$ for the As-series melted in a PtAu crucible.

The hafnium solubility also depends on the glass composition. At $1400^{\circ} \mathrm{C}$ in oxidizing conditions, the Bs-serie glasses exhibit a solubility of 5.5-6 mol\% and the As-series, a slightly higher of 6-6.5 mol\% $\mathrm{HfO}_{2}$. Furthermore, glasses melted in C-SiC crucibles (AS7 and BS2 glasses) exhibit lower solubilities than glasses elaborated in Pt-Au or $\mathrm{C}_{\mathrm{g}}$ crucibles (AS5, BS4 and BS5 glasses): 4.5 mol\% $\mathrm{HfO}_{2}$ for A melts and 3.5-4 mol\% $\mathrm{HfO}_{2}$ for $\mathrm{B}$ melts. This can be explained by the use of $\mathrm{C}$-SiC crucible that interacts with the glasses and modifies their compositions. Indeed, at high temperature, the mullite binder $\left(3 \mathrm{Al}_{2} \mathrm{O}_{3}-2 \mathrm{SiO}_{2}\right)$ diffuses in the glass as proven by the enrichment of $\mathrm{Al}_{2} \mathrm{O}_{3}$ and $\mathrm{SiO}_{2}$ in $\mathrm{AS7}$ and $\mathrm{BS} 2$ samples (Table 4).

\section{Table 4}

Glass compositions (mol\%) determined by microprobe (EDS) and crystalline phases observed for different elaboration conditions. The $\mathrm{M}^{*}$ ratio is expressed as molar $\left(\mathrm{CaO}+\mathrm{Na}_{2} \mathrm{O}\right) /\left(\mathrm{CaO}+\mathrm{Na}_{2} \mathrm{O}+\mathrm{Al}_{2} \mathrm{O}_{3}\right)$ ratio. The random standard uncertainty is calculated by multiplying the standard deviation of the mean and the student t-factor at the $95 \%$ level of confidence.

\begin{tabular}{|c|c|c|c|c|c|c|c|c|c|c|c|c|}
\hline $\begin{array}{l}\text { Glass } \\
\text { Name }\end{array}$ & $\begin{array}{l}\text { Starting } \\
\text { glass }\end{array}$ & $\begin{array}{c}\text { Temperature } \\
\left({ }^{\circ} \mathrm{C}\right)\end{array}$ & $\begin{array}{l}\text { Redox } \\
\text { conditions }\end{array}$ & $\begin{array}{l}\text { Added } \\
\mathrm{HfO}_{2}, \\
\left(\mathrm{~mol}^{2}\right)\end{array}$ & $\begin{array}{l}\mathrm{SiO}_{2} \\
\left(\mathrm{~mol}^{2} \%\right)\end{array}$ & $\begin{array}{l}\mathrm{Al}_{2} \mathrm{O}_{3} \\
(\mathrm{~mol} \%)\end{array}$ & $\begin{array}{c}\mathrm{CaO} \\
(\mathrm{mol} \%)\end{array}$ & $\begin{array}{l}\mathrm{Na}_{2} \mathrm{O} \\
(\mathrm{mol} \%)\end{array}$ & $\begin{array}{l}\mathrm{HfO}_{2} \\
\left(\mathrm{~mol}^{2}\right)\end{array}$ & $\begin{array}{l}\mathrm{Fe}_{2} \mathrm{O}_{3} \\
(\mathrm{~mol} \%)\end{array}$ & $\begin{array}{l}\text { Crystalline } \\
\text { phases }\end{array}$ & $M^{*}$ \\
\hline AS1 & $A$ & 1250 & Pt-Au & 1.5 & $\begin{array}{c}57.30 \\
+/- \\
0.10\end{array}$ & $\begin{array}{c}6.30 \\
+/- \\
0.03\end{array}$ & $\begin{array}{c}13.91 \\
+/- \\
0.05\end{array}$ & $\begin{array}{c}20.82 \\
+/- \\
0.08\end{array}$ & $\begin{array}{c}1.66 \\
+/- \\
0.05\end{array}$ & 0 & None & 0.85 \\
\hline AS2 & $A$ & 1250 & Pt-Au & 4.0 & $\begin{array}{l}57.54 \\
+/- \\
0.30\end{array}$ & $\begin{array}{c}6.34 \\
+/- \\
0.07\end{array}$ & $\begin{array}{l}13.78 \\
+/- \\
0.09\end{array}$ & $\begin{array}{l}19.25 \\
+/- \\
0.24\end{array}$ & $\begin{array}{l}3.09 \\
+/- \\
0.08\end{array}$ & 0 & $\begin{array}{c}\mathrm{Na}_{4} \mathrm{Hf}_{2}\left(\mathrm{SiO}_{4}\right)_{3}, \\
\mathrm{HfO}_{2}\end{array}$ & 0.84 \\
\hline AS3 & $A$ & 1250 & C-SiC & 2.5 & $\begin{array}{l}62.44 \\
+/- \\
0.49\end{array}$ & $\begin{array}{c}7.72 \\
+/- \\
0.12\end{array}$ & $\begin{array}{c}13.41 \\
+/- \\
0.49\end{array}$ & $\begin{array}{l}13.90 \\
+/- \\
0.39\end{array}$ & $\begin{array}{l}2.53 \\
+/- \\
0.07\end{array}$ & $\begin{array}{l}0.31 \\
+/- \\
0.03\end{array}$ & None & 0.78 \\
\hline AS4 & $A$ & 1400 & Pt-Au & 5.0 & $\begin{array}{c}55.60 \\
+/- \\
0.12\end{array}$ & $\begin{array}{l}6.02 \\
+/- \\
0.04\end{array}$ & $\begin{array}{c}13.20 \\
+/- \\
0.06\end{array}$ & $\begin{array}{l}20.01 \\
+/- \\
0.08\end{array}$ & $\begin{array}{l}5.17 \\
+/- \\
0.09\end{array}$ & 0 & None & 0.85 \\
\hline AS5 & A & 1400 & $\mathrm{Pt}-\mathrm{Au}$ & 7.0 & $\begin{array}{c}55.19 \\
+/- \\
0.09\end{array}$ & $\begin{array}{c}6.13 \\
+/- \\
0.03\end{array}$ & $\begin{array}{c}13.28 \\
+/- \\
0.12\end{array}$ & $\begin{array}{c}19.36 \\
+/- \\
0.16\end{array}$ & $\begin{array}{l}6.04 \\
+/- \\
0.07\end{array}$ & 0 & $\begin{array}{c}\mathrm{Na}_{4} \mathrm{Hf}_{2}\left(\mathrm{SiO}_{4}\right)_{3}, \\
\mathrm{HfO}_{2}\end{array}$ & 0.84 \\
\hline AS6 & A & 1400 & C-SiC & 3.0 & $\begin{array}{c}65.02 \\
+/- \\
0.91\end{array}$ & $\begin{array}{c}7.95 \\
+/- \\
0.30\end{array}$ & $\begin{array}{c}13.17 \\
+/- \\
0.92\end{array}$ & $\begin{array}{c}10.59 \\
+/- \\
0.53\end{array}$ & $\begin{array}{c}3.02 \\
+/- \\
0.15\end{array}$ & $\begin{array}{c}0.26 \\
+/- \\
0.04\end{array}$ & Dendrites & 0.75 \\
\hline AS7 & $A$ & 1400 & C-SiC & 7.0 & $\begin{array}{c}65.77 \\
+/- \\
0.17\end{array}$ & $\begin{array}{c}8.60 \\
+/- \\
0.09\end{array}$ & $\begin{array}{c}11.98 \\
+/- \\
0.46\end{array}$ & $\begin{array}{c}8.93 \\
+/- \\
0.17\end{array}$ & $\begin{array}{c}4.52 \\
+/- \\
0.08\end{array}$ & $\begin{array}{c}0.21 \\
+/- \\
0.17\end{array}$ & $\mathrm{HfO}_{2}$ & 0.71 \\
\hline BS1 & B & 1400 & C-SiC & 3.5 & $\begin{array}{c}61.16 \\
+/- \\
0.24\end{array}$ & $\begin{array}{c}7.50 \\
+/- \\
0.05\end{array}$ & $\begin{array}{c}28.27 \\
+/- \\
0.22\end{array}$ & 0 & $\begin{array}{c}3.07 \\
+/- \\
0.07\end{array}$ & 0 & None & 0.79 \\
\hline BS2 & B & 1400 & C-SiC & 7.0 & $\begin{array}{c}61.77 \\
+/- \\
0.37\end{array}$ & $\begin{array}{c}8.49 \\
+/- \\
0.23\end{array}$ & $\begin{array}{c}24.60 \\
+/- \\
0.78\end{array}$ & $\begin{array}{c}1.07 \\
+/- \\
0.21\end{array}$ & $\begin{array}{c}3.56 \\
+/- \\
0.14\end{array}$ & $\begin{array}{c}0.51 \\
+/- \\
0.21\end{array}$ & $\mathrm{HfSiO}_{4}, \mathrm{HfO}_{2}$ & 0.75 \\
\hline BS3 & B & 1400 & Pt-Au & 3.0 & $\begin{array}{c}56.65 \\
+/- \\
0.07\end{array}$ & $\begin{array}{c}6.23 \\
+/- \\
0.02\end{array}$ & $\begin{array}{c}34.11 \\
+/- \\
0.11\end{array}$ & 0 & $\begin{array}{c}3.02 \\
+/- \\
0.06\end{array}$ & 0 & None & 0.85 \\
\hline BS4 & B & 1400 & Pt-Au & 7.0 & $\begin{array}{c}54.92 \\
+/- \\
0.05\end{array}$ & $\begin{array}{c}6.55 \\
+/- \\
0.03\end{array}$ & $\begin{array}{c}32.91 \\
+/- \\
0.09\end{array}$ & 0 & $\begin{array}{c}5.61 \\
+/- \\
0.06\end{array}$ & 0 & $\begin{array}{c}\mathrm{Ca}_{2} \mathrm{HfSi}_{4} \mathrm{O}_{12}, \\
\mathrm{HfSiO}_{4},\end{array}$ & 0.83 \\
\hline
\end{tabular}


$\mathrm{HfO}_{2}$

\begin{tabular}{|c|c|c|c|c|c|c|c|c|c|c|c|c|}
\hline BS5 & B & 1400 & $C_{g}$ & 7.0 & $\begin{array}{c}55.00 \\
+/- \\
0.11\end{array}$ & $\begin{array}{c}6.12 \\
+/- \\
0.03\end{array}$ & $\begin{array}{c}32.89 \\
+/- \\
0.11\end{array}$ & 0 & $\begin{array}{c}5.99 \\
+/- \\
0.05\end{array}$ & 0 & $\begin{array}{c}\mathrm{HfSiO}_{4} \\
\mathrm{HfO}_{2}\end{array}$ & 0.84 \\
\hline
\end{tabular}

\subsubsection{Hafnium crystallization}

The mineralogy of the different crystals-bearing glasses above the $\mathrm{HfO}_{2}$ solubility limit changes with the glass composition and the redox conditions (Table 4). For the A-series glasses elaborated in oxidizing conditions $\left(1250^{\circ} \mathrm{C}\right.$ or $\left.1400^{\circ} \mathrm{C}\right)$, the main crystallized phase is hexagonal $\mathrm{Na}_{4} \mathrm{Hf}_{2}\left(\mathrm{SiO}_{3}\right)_{4}$ as shown in Figure 6 and Figure $7 \mathrm{~b}$. The Rietveld refinement attests that those crystals represent $79 \mathrm{wt} \%$ of the whole crystalline phases attended (Table 5). Monoclinic $\mathrm{HfO}_{2}$ crystals (21 wt\%) are also identified by both XRD and SEM/EDS.

In the A-series melted in $\mathrm{C}$-SiC crucible at $1400^{\circ} \mathrm{C}$, the only $\mathrm{Hf}$-bearing crystallized phase is $\mathrm{HfO}_{2}$. Some cristobalite $\left(\mathrm{SiO}_{2}\right)$ is also detected (around $30 \mathrm{wt} \%$ ). At lower temperature, the other crystalline phase (40 wt\%) seems to correspond to the triclinic parakeldyshite $\mathrm{Na}_{2} \mathrm{ZrSi}_{2} \mathrm{O}_{7}$ phase [26]. Because of the possible cross-substitution of $\mathrm{Zr}$ and Hf, the formula of the observed crystalline phase in Figure $7 \mathrm{a}$ might correspond to $\mathrm{Na}_{2} \mathrm{HfSi}_{2} \mathrm{O}_{7}$. This stoichiometry is confirmed by EDS analysis of the crystal (Table 6). Na migration under electron beam may explain the slight drop between the analysis and the pure phase stoichiometry. EDS analysis also suggests that a substitution of $\mathrm{Na}_{2} \mathrm{O}$ by $\mathrm{CaO}$ is also likely to occur in that crystal. Since no XRD pattern of $\mathrm{Na}_{2} \mathrm{HfSi}_{2} \mathrm{O}_{7}$ is referenced in the literature to our knowledge, we have first considered the same space group for $\mathrm{Na}_{2} \mathrm{Hf}_{2} \mathrm{SiO}_{7}$ than for parakeldyshite. The atomic positions of parakeldyshite were used with a complete substitution of $\mathrm{Zr}$ by Hf. The Rietveld refinement of the XRD pattern is consistent with this result, as shown by the $x 2$ equal to 4.9 (Figure 8). The cell parameters of the $\mathrm{Na}_{2} \mathrm{HfSi}_{2} \mathrm{O}_{7}$ crystalline phase are extracted from the refinement and given in Table 7 . In order to validate the refinement, the sodium hafnium disilicate $\mathrm{Na}_{2} \mathrm{HfSi}_{2} \mathrm{O}_{7}$ was synthetized and its structure was refined. The triclinic space group was confirmed and the atomic positions were determined [27].

For the B-series glasses ( $\mathrm{Na}$-free) elaborated in oxidizing conditions, monoclinic $\mathrm{Ca}_{2} \mathrm{HfSi}_{4} \mathrm{O}_{12}$, tetragonal $\mathrm{HfSiO}_{4}$ and $\mathrm{HfO}_{2}$ crystals are observed by SEM (Figure 7d) and detected by XRD (Figure 6). The main phase is $\mathrm{Ca}_{2} \mathrm{HfSi}_{4} \mathrm{O}_{12}(89 \mathrm{wt} \%)$ and other phases are $\mathrm{HfO}_{2}(6 \mathrm{wt} \%)$ and $\mathrm{HfSiO}_{4}(5 \mathrm{wt} \%)$. In reducing conditions, the crystallized phases are $\mathrm{HfSiO}_{4}$ and $\mathrm{HfO}_{2}$ according to XRD results (Figure 6). For glasses melted in $\mathrm{C}$-SiC crucibles, $\mathrm{HfO}_{2}$ crystals are not detected by XRD (certainly below the device detection limit) but some tiny ones (few hundred of nanometers) are shown up in SEM images (Figure 7c). However, XRD patterns often show the presence of graphite carbon and silicon carbide. These impurities come from the reaction between glass and $\mathrm{C}-\mathrm{SiC}$ crucible at the glass/crucible interface. A thin layer belonging to the $\mathrm{C}$-SiC crucible was systematically observed on the sample surface after heating. So a variable part of this layer could be introduced in the sample during the XRD preparation. The $\mathrm{C}$ and $\mathrm{SiC}$ content are not taken into account in the crystalline phase percentage calculation. 


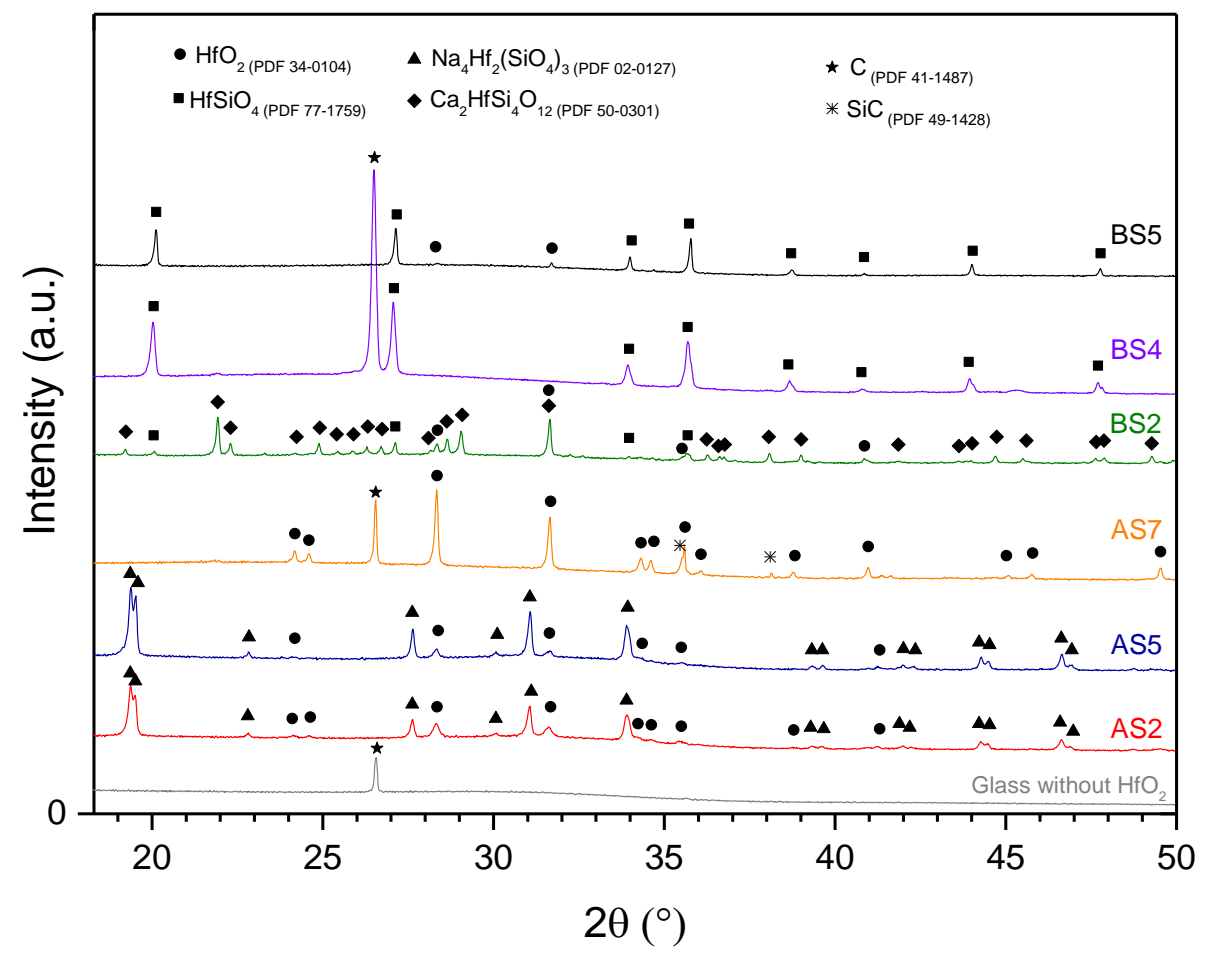

Figure 6. XRD patterns of $\mathrm{Hf}$-doped glasses elaborated in oxidizing and reducing conditions at $1250^{\circ} \mathrm{C}$ or $1400^{\circ} \mathrm{C}$. The glass sample without adding $\mathrm{HfO}_{2}$ was melted in $\mathrm{C}-\mathrm{SiC}$ crucible at $1400^{\circ} \mathrm{C}$ for $3 \mathrm{~h}$. Note that the enlarge part of patterns between $2 \theta=18-50^{\circ}$ is shown to get better insight of the diffraction peaks due to the crystallization. 

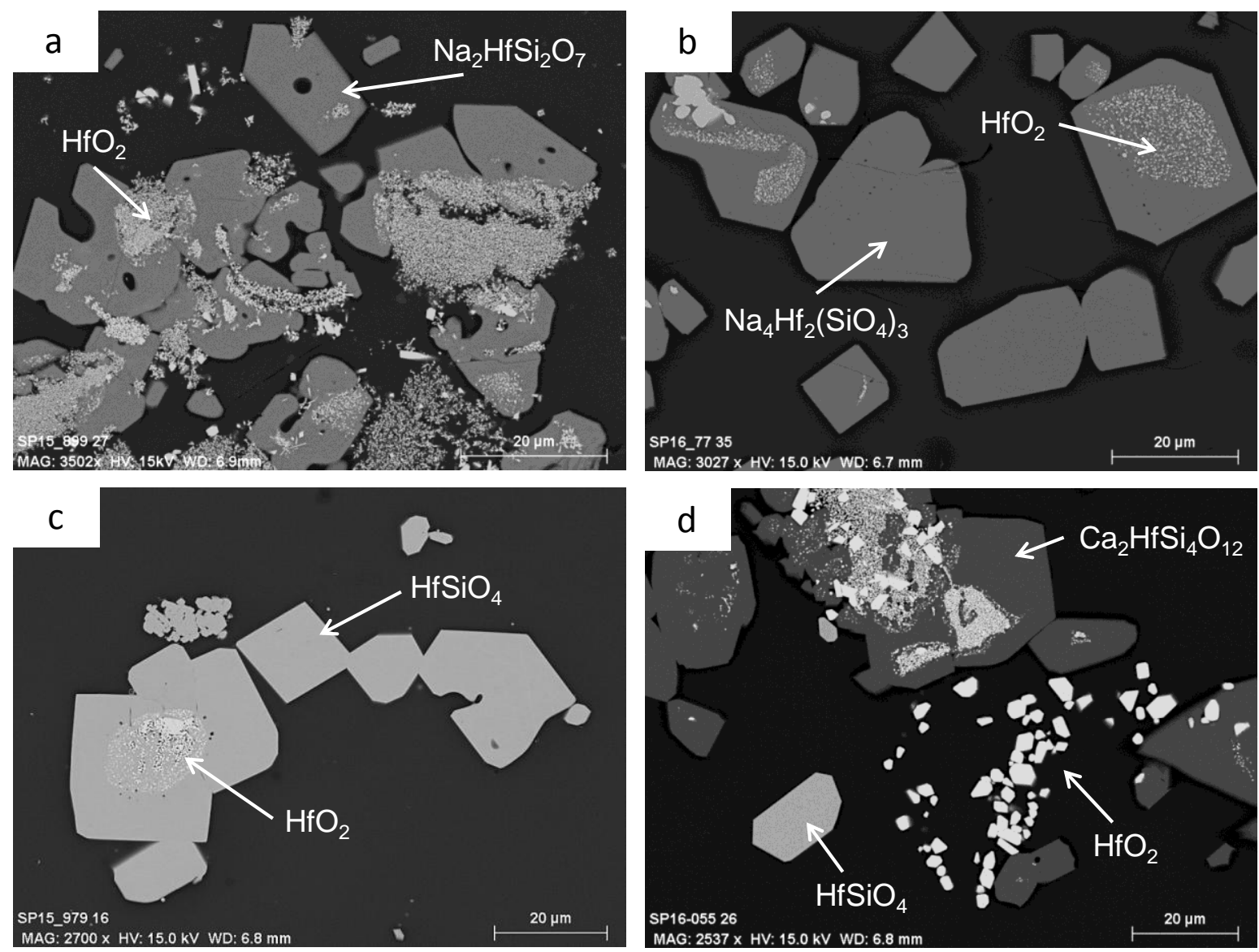

Figure 7. SEM images of crystals in $\mathrm{HfO}_{2}$-saturated glasses from A starting glass (a) at $1250^{\circ} \mathrm{C}$ in $\mathrm{C}$-SiC crucible, (b) at $1250^{\circ} \mathrm{C}$ or $1400^{\circ} \mathrm{C}$ in Pt-Au crucible and from B starting glass at $1400^{\circ} \mathrm{C}$ (c) in $\mathrm{C}-\mathrm{SiC}$ or $\mathrm{C}$ crucibles, (d) in Pt-Au crucible.

\section{Table 5}

Relative percentage in mass of some crystals in glass, data obtained after the Rietveld refinement of crystallized glass samples. Error for each crystal is $\pm 2 \mathrm{wt} \%$.

Crystal mass fraction (wt\%)

\section{Glass}

$$
\mathrm{Ca}_{2} \mathrm{HfSi}_{4} \mathrm{O}_{12} \quad \mathrm{Na}_{4} \mathrm{Hf}_{2} \mathrm{Si}_{3} \mathrm{O}_{13} \quad \mathrm{Na}_{2} \mathrm{HfSi}_{2} \mathrm{O}_{7} \quad \mathrm{HfSiO}_{4} \quad \mathrm{HfO}_{2} \quad \mathrm{SiO}_{2}
$$

\begin{tabular}{|c|c|c|c|c|c|c|c|}
\hline AS2 & - & $79 \%$ & - & - & $21 \%$ & - & 3.5 \\
\hline AS5 & - & $93 \%$ & - & - & $7 \%$ & - & 4.2 \\
\hline AS8 & - & - & $40 \%$ & - & $60 \%$ & - & 4.9 \\
\hline AS7 & - & - & - & - & $70 \%$ & $30 \%$ & 2.5 \\
\hline BS4 & $89 \%$ & - & - & $5 \%$ & $6 \%$ & - & 5.2 \\
\hline BS2 & - & - & - & $100 \%$ & - & - & 6.4 \\
\hline
\end{tabular}


* Reduced chi square is an indicator of the fit goodness as determined in [21].

\section{Table 6}

Composition of the observed $\mathrm{Na}_{2} \mathrm{HfSi}_{2} \mathrm{O}_{7}$ crystalline phase determined by microprobe (EDS) in the studied sample (AS8) and compared to the stoichiometric one.

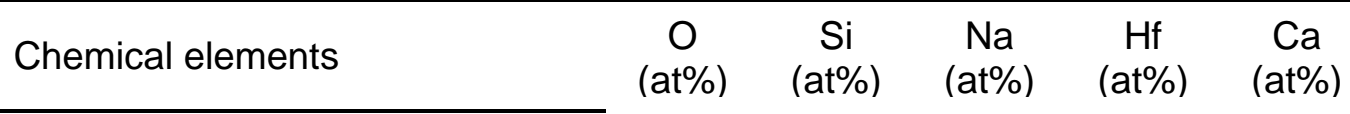

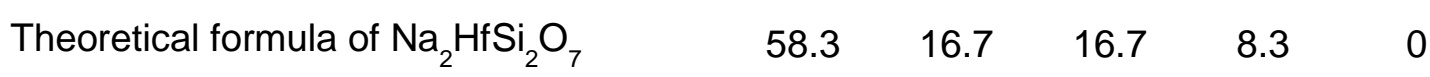

Measured composition of the $\mathrm{Na}_{2} \mathrm{HfSi}_{2} \mathrm{O}_{7}$ crystal $\quad 60.1 \quad 17.6 \quad 11.6 \quad 8.4 \quad 2.4$

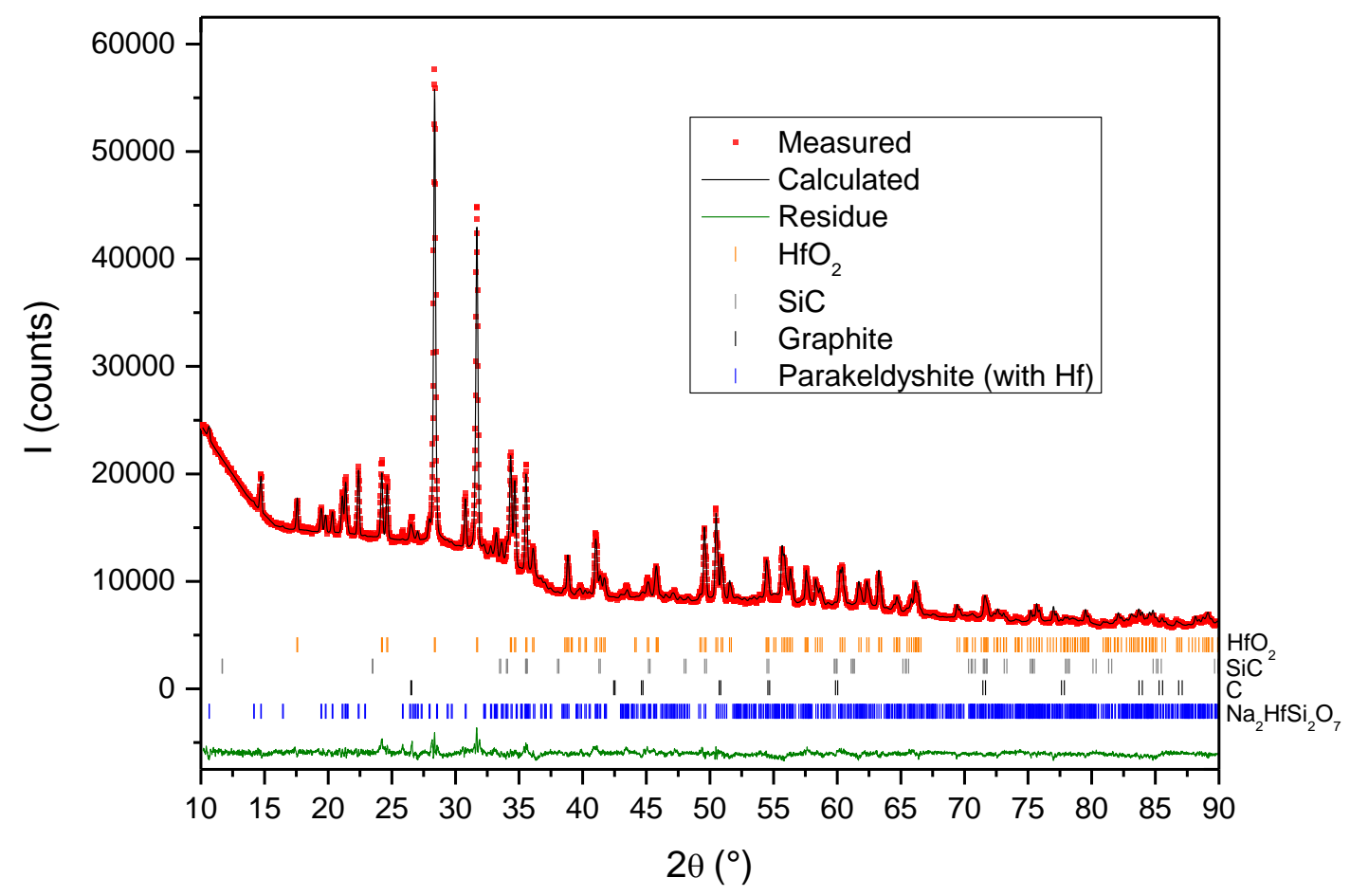

Figure 8. Rietveld refinement of XRD pattern containing the detected $\mathrm{Na}_{2} \mathrm{HfSi}_{2} \mathrm{O}_{7}$ crystalline phase in the $\mathrm{A}$ glass with $10 \mathrm{~mol} \% \mathrm{HfO}_{2}$ melted in $\mathrm{C}-\mathrm{SiC}$ at $1250^{\circ} \mathrm{C}$ (AS8). 


\section{Table 7}

Cell parameters ( $a, b, c, \alpha, \beta, y$ and cell volumes) of the $\mathrm{Na}_{2} \mathrm{HfSi}_{2} \mathrm{O}_{7}$ crystals present in the studied sample, extracted from the whole pattern decomposition, and of the triclinic $\mathrm{Na}_{2} \mathrm{ZrSi}_{2} \mathrm{O}_{7}$ crystals.

\begin{tabular}{|c|c|c|c|c|c|c|c|c|}
\hline $\begin{array}{l}\text { Crystalline } \\
\text { phase }\end{array}$ & $a(\AA)$ & $b(\AA)$ & $c(\AA)$ & $\alpha\left({ }^{\circ}\right)$ & $\beta\left({ }^{\circ}\right)$ & $Y\left({ }^{\circ}\right)$ & $V\left(\AA^{3}\right)$ & Ref \\
\hline $\mathrm{Na}_{2} \mathrm{HfSi}_{2} \mathrm{O}_{7}$ & $\begin{array}{c}6.6232 \\
+/- \\
0.0060\end{array}$ & $\begin{array}{c}8.7881 \\
+/- \\
0.0075\end{array}$ & $\begin{array}{c}5.4046 \\
+/- \\
0.0047\end{array}$ & $\begin{array}{c}92.25 \\
+/- \\
0.09\end{array}$ & $\begin{array}{c}93.88 \\
+/- \\
0.07\end{array}$ & $\begin{array}{c}71.10 \\
+/- \\
0.06\end{array}$ & $\begin{array}{c}296.89 \\
+/- \\
0.45\end{array}$ & $\begin{array}{l}\text { This } \\
\text { study }\end{array}$ \\
\hline $\mathrm{Na}_{2} \mathrm{ZrSi}_{2} \mathrm{O}_{7}$ & 6.6364 & 8.8120 & 5.4233 & 92.69 & 94.20 & 71.36 & 299.6 & [26] \\
\hline
\end{tabular}

$\mathrm{Hf}$-bearing crystals display different forms (Figure 7). $\mathrm{HfO}_{2}$ gets two types of crystal sizes, several hundred nanometers and several microns. Micrometric crystals are located in the glass and have an isometric shape while nanometric $\mathrm{HfO}_{2}$ are often observed inside the $\mathrm{Hf}$ silicate crystals. These silicate crystals have an isometric shape and range in size from 10 $\mu \mathrm{m}$ to $50 \mu \mathrm{m}$. Other crystal morphologies are also observed in the A-series fused in C-SiC at $1400^{\circ} \mathrm{C}$ (Figure 9). These hafnium crystals are located at the interface between the glass and the crucible and display several forms such as needle (Figure 10a), dendrite (Figure 10b and c) and crown (Figure 10d) shapes. Surrounding these crystals, a depletion of $\mathrm{HfO}_{2}$ and $\mathrm{CaO}$ and an enrichment of other oxides $\left(\mathrm{SiO}_{2}\right.$ and $\left.\mathrm{Al}_{2} \mathrm{O}_{3}\right)$ are noticed (Table 8). Those crystals are not observed using Pt-Au crucibles.

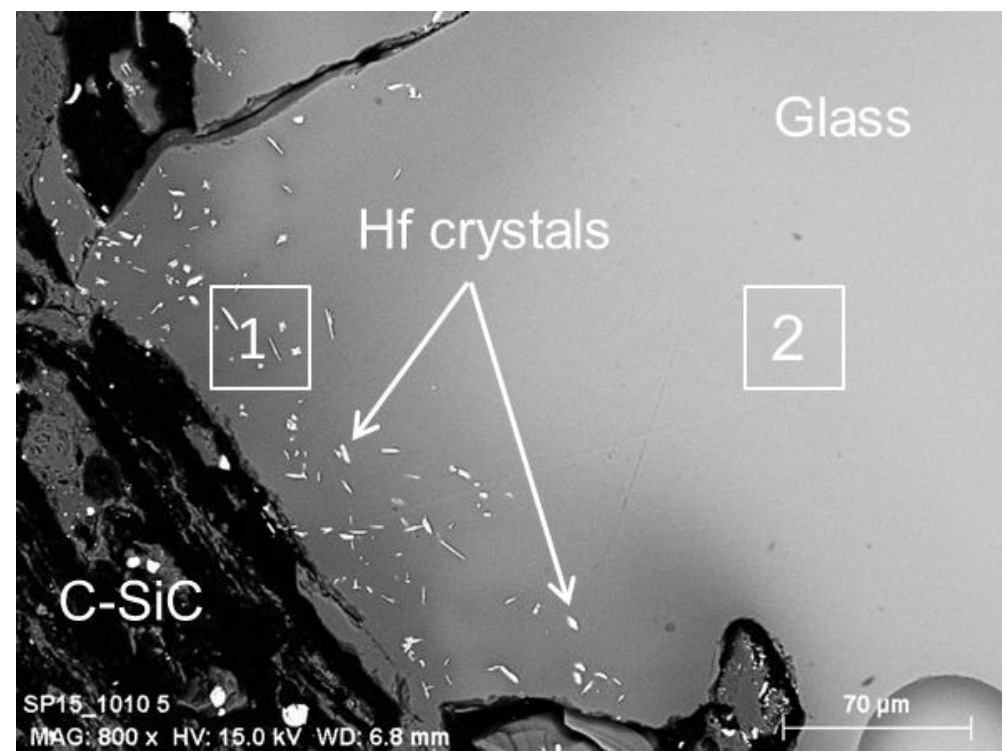

Figure 9. SEM image of the interface between the C-SiC crucible and the glass in the AS6 sample, showing (1) and (2) different areas. 


\section{Table 8}

Glass compositions of two areas; (1) close to the interface between the C-SiC crucible and the glass and (2) far from this interface; determined by microprobe (EDS) in the AS6 sample.

\begin{tabular}{ccccccc}
\hline $\begin{array}{c}\text { Point of } \\
\text { analysis }\end{array}$ & $\begin{array}{c}\mathrm{SiO}_{2} \\
(\mathrm{~mol} \%)\end{array}$ & $\begin{array}{c}\mathrm{Al}_{2} \mathrm{O}_{3} \\
(\mathrm{~mol} \%)\end{array}$ & $\begin{array}{c}\mathrm{CaO} \\
(\mathrm{mol} \%)\end{array}$ & $\begin{array}{c}\mathrm{Na}_{2} \mathrm{O} \\
(\mathrm{mol} \%)\end{array}$ & $\begin{array}{c}\mathrm{HfO}_{2} \\
(\mathrm{~mol} \%)\end{array}$ & $\begin{array}{c}\mathrm{Fe}_{2} \mathrm{O}_{3} \\
(\mathrm{~mol} \%)\end{array}$ \\
\hline 1 & 77.63 & 9.44 & 2.71 & 7.81 & 2.30 & 0.11 \\
2 & 67.85 & 8.42 & 10.75 & 8.39 & 4.31 & 0.29 \\
\hline
\end{tabular}
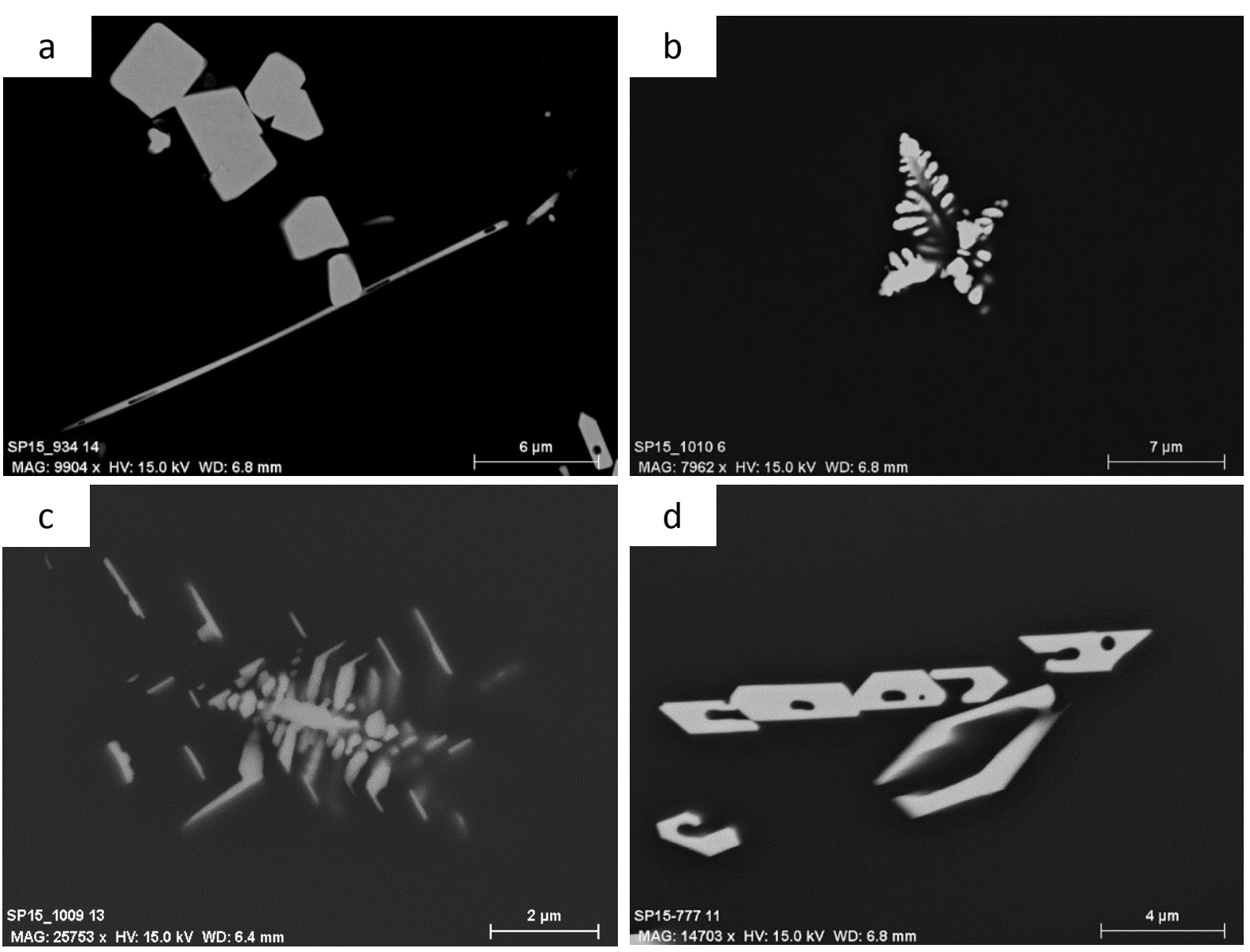

Figure 10. SEM images of Hf-bearing crystals observed in Hf-doped A glasses melted in C-SiC crucible at $1400^{\circ} \mathrm{C}$ with several morphologies (a) needle shaped, (b,c) dendritic shaped and (d) crown shaped .

\section{Discussion}

\subsection{Hafnium incorporation}

Hafnium sedimentation may be explained by the huge density difference between $\mathrm{HfO}_{2}$ precursor and the glass. Measured glass densities are respectively, $2.59 \mathrm{~g} . \mathrm{cm}^{-3}$ and 2.68 $\mathrm{g} . \mathrm{cm}^{-3}$ for $\mathrm{A}$ and $\mathrm{C}$ glasses in contrast to $9.68 \mathrm{~g} . \mathrm{cm}^{-3}$ for $\mathrm{HfO}_{2}$. Experimental measurements indicate that $A$ and $C$ melt viscosities are below $200 \mathrm{dPa}$.s at $1250^{\circ} \mathrm{C}$ and close to $50 \mathrm{dPa} . \mathrm{s}$ at $1400^{\circ} \mathrm{C}$ (Figure 11). Hafnium addition in the glass network increases slightly the melt 
viscosity but not enough to avoid $\mathrm{HfO}_{2}$ sedimentation. In a laminar flow, the sedimentation velocity $\left({\left.\mathrm{m} . \mathrm{s}^{-1}\right)}\right)$ of spherical particles in a melt can be described by the Stokes' law:

$v=\frac{2 r^{2} g\left(\rho_{\text {particle }}-\rho_{\text {fluid }}\right)}{9 \eta}$

with $r$, the particle radius $(\mathrm{m})$

$g$, the standard acceleration $\left(\mathrm{m}_{\mathrm{s}} \mathrm{s}^{-2}\right)$

$\rho$, the density $\left(\mathrm{kg} \cdot \mathrm{cm}^{-3}\right)$

$\eta$, the fluid viscosity (Pa.s)

Considering these hypotheses (laminar flow and spherical particles) and equation (1), 158 $\mu \mathrm{m}$ diameter $\mathrm{HfO}_{2}$ particles in $\mathrm{A}$ melt fall in about 15 min from the top to the bottom of the glass sample (around $6 \mathrm{~mm}$ ) at $1250^{\circ} \mathrm{C}$ and more rapidly in $5 \mathrm{~min}$ at $1400^{\circ} \mathrm{C}$. $\mathrm{HfO}_{2}$ sedimentation is accelerated at $1400^{\circ} \mathrm{C}$, while hafnium diffusion into the glass melt is enhanced. Equation (1) also shows that decreasing $\mathrm{HfO}_{2}$ particle size drastically slows down the sedimentation velocity. At $1250^{\circ} \mathrm{C}, 70 \mu \mathrm{m}$ diameter $\mathrm{HfO}_{2}$ particles fall in 75 min and 15 $\mu \mathrm{m}$ diameter $\mathrm{HfO}_{2}$ particles in more than one day. This effect has to be coupled with the increase in $\mathrm{Hf}$ precursors dissolution kinetics for smaller initial particle sizes [28], both leading to a better $\mathrm{HfO}_{2}$ incorporation.

When equilibrium is not established, $\mathrm{HfO}_{2}$ sedimentation widely limits its incorporation into the glass matrix. At the bottom of the crucible, the glass melt surrounding crystals is supersaturated in hafnium which largely slows down $\mathrm{HfO}_{2}$ crystals dissolution into the whole glass sample. Furthermore, increasing duration could make the sedimentation layer denser [6] and thus makes it harder to dissolve crystals. In that case, crystallization is due to the presence of undissolved particles, relicts of hafnium oxide particles introduced into the initial powder mixture or to new formed crystals.

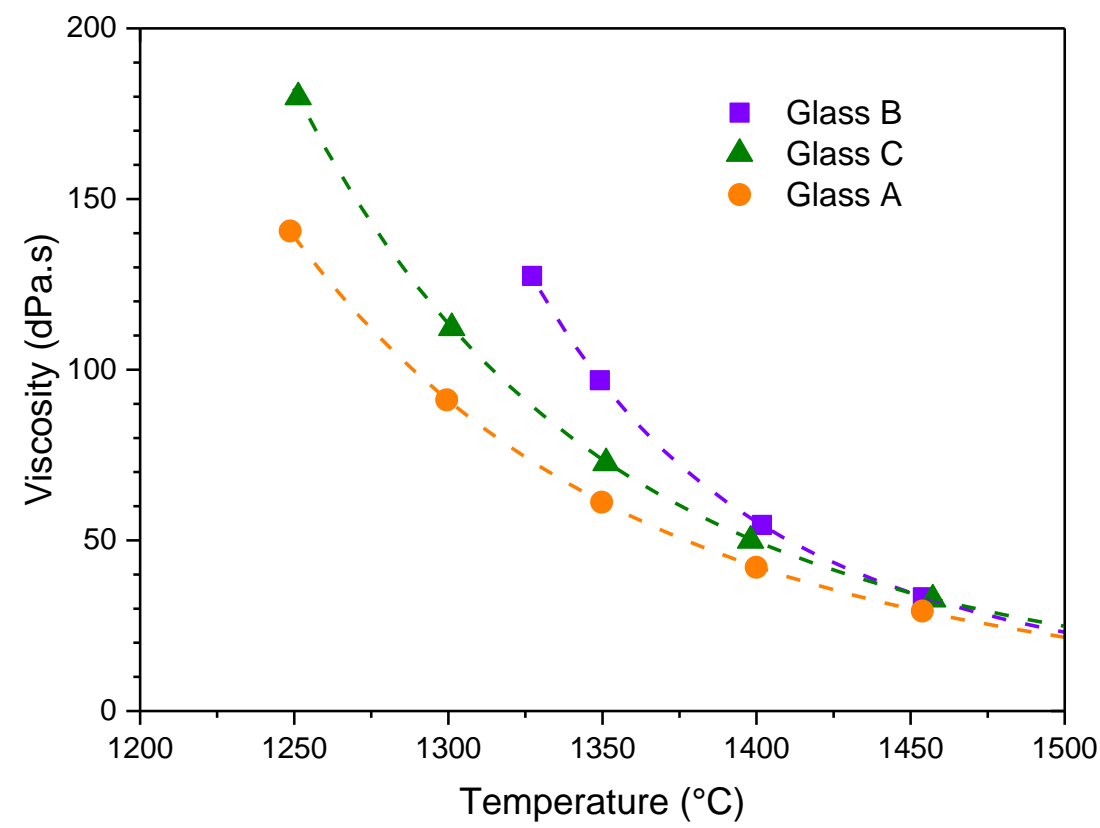

Figure 11. Steady state viscosity of glass melts for different compositions as a function of the temperature. The dash lines represent the VFT model and the symbols are the measured data. Note that all glasses are totally homogeneous within the measuring range. 


\subsection{Hafnium solubility}

Our hafnium solubility results may now be compared to other studies. In this work, we show that the redox conditions do not affect the $\mathrm{HfO}_{2}$ solubility which is consistent with the fact that $\mathrm{Hf}$ displays only one oxidation state in the glass, namely $\mathrm{Hf}^{\mathrm{lV}}$. Therefore the $\mathrm{HfO}_{2}$ solubilization mechanism must be the same for reduced or oxidized glass melts.

A higher melting temperature improves the $\mathrm{HfO}_{2}$ solubility limits as commonly observed by authors $[10,20,24]$. Since the oxidation state is fixed $\left(\mathrm{Hf}^{\mathrm{IV}}\right)$, the enhancing of the solubility is only controlled by the temperature.

The interpretation of the $\mathrm{HfO}_{2}$ solubility in aluminosilicate glass as a function of the glass composition is based on previous studies. For peralkaline glass, Davis [8] has demonstrated that the hafnium solubility is strongly and positively related to the excess of alkalis which are not used for charge compensation. We can define the following $\mathrm{M}^{*}$ ratio (with the oxide content in $\mathrm{mol} \%)$ :

$M^{*}=\frac{M^{\prime} O+M^{\prime \prime}{ }_{2} O}{M^{\prime} O+M^{\prime \prime}{ }_{2} O+A l_{2} O_{3}}(2)$

where $\mathrm{M}^{\prime}$ and $\mathrm{M}^{\prime \prime}$ are respectively metal divalent and monovalent cations. According to Davis, for peralkaline glasses $\left(M^{*} \geq 0.5\right)$, the hafnium solubility increases with $M^{*}$. Applied to our case $\mathrm{M}^{*}$ is written:

$M^{*}=\frac{\mathrm{CaO}+\mathrm{Na}_{2} \mathrm{O}}{\mathrm{CaO}+\mathrm{Na}_{2} \mathrm{O}+\mathrm{Al}_{2} \mathrm{O}_{3}}$

All our glass samples have $\mathrm{M}^{*}>0.5$ (Table 4) and belong to the peralkaline field. Glass samples melted in C-SiC crucibles present a lower $M^{*}(0.71$ and 0.74 for AS7 and BS2 samples) than glasses fused in other crucibles $(0.84$ and 0.83 for AS5, BS4 and BS5 samples). For AS7 glass sample, the lessening of $\mathrm{M}^{*}$ is accentuated by Na volatilization. $A$ decrease in $\mathrm{HfO}_{2}$ solubility is observed as $\mathrm{M}^{*}$ decreases (Table 3). Indeed, for AS7 and BS2 glasses, the melt compositions are enriched in $\mathrm{Al}_{2} \mathrm{O}_{3}$ and $\mathrm{SiO}_{2}$ because of the mullite binder from the crucible, hence show a lower excess of alkalis or alkaline earths. Nevertheless, a slight solubility difference is observed between AS5 and BS4 glasses although their respective $\mathrm{M}^{*}$ are comparable. Therefore, it seems that the nature of cations may play a small role. Some authors $[14,15]$ have shown that, in peralkaline melts, the increase of the $\mathrm{M}$ 'O/M" ${ }_{2} \mathrm{O}$ ratio smoothly enhances the solubilities of +4 cations (for instance, $\mathrm{Ti}$ and $\mathrm{Zr}$ ). Thus, the substitution of $\mathrm{Na}_{2} \mathrm{O}$ by $\mathrm{CaO}$ should slightly decrease the hafnium solubility as observed. When $\mathrm{M}^{*}$ is higher than 0.5 , these cations act both as network modifiers and charge compensators in the aluminosilcate network. Classically, $\mathrm{Ca}^{2+}$ serves as a charge balancing for two $\mathrm{AlO}_{4}$ tetrahedrons or two non-bridging oxygens and $\mathrm{Na}^{+}$charge balancing for one $\mathrm{AlO}_{4}$ tetrahedron or one non-bridging oxygen. Ca might cause a steric hindrance more significant than $\mathrm{Na}$. This assumption to explain the low $\mathrm{HfO}_{2}$ solubility difference between AS5 and BS4 melts needs further experiments to confirm it.

Figure 12 presents our results compared to previous studies, with the $\mathrm{HfO}_{2}$ solubility plotted as a function of the $\mathrm{M}^{*}$ ratio. The $\mathrm{HfO}_{2}$ solubility is higher in peralkaline glasses than in peraluminous ones and borosilicate glasses tend to exhibit higher hafnium solubilities than aluminosilicate glasses. For the borosilicate glasses, the melting temperature is $50^{\circ} \mathrm{C}$ higher than in aluminosilicate glasses. Boron appears to improve the $\mathrm{HfO}_{2}$ solubility but its role still remains unclear [8]. 


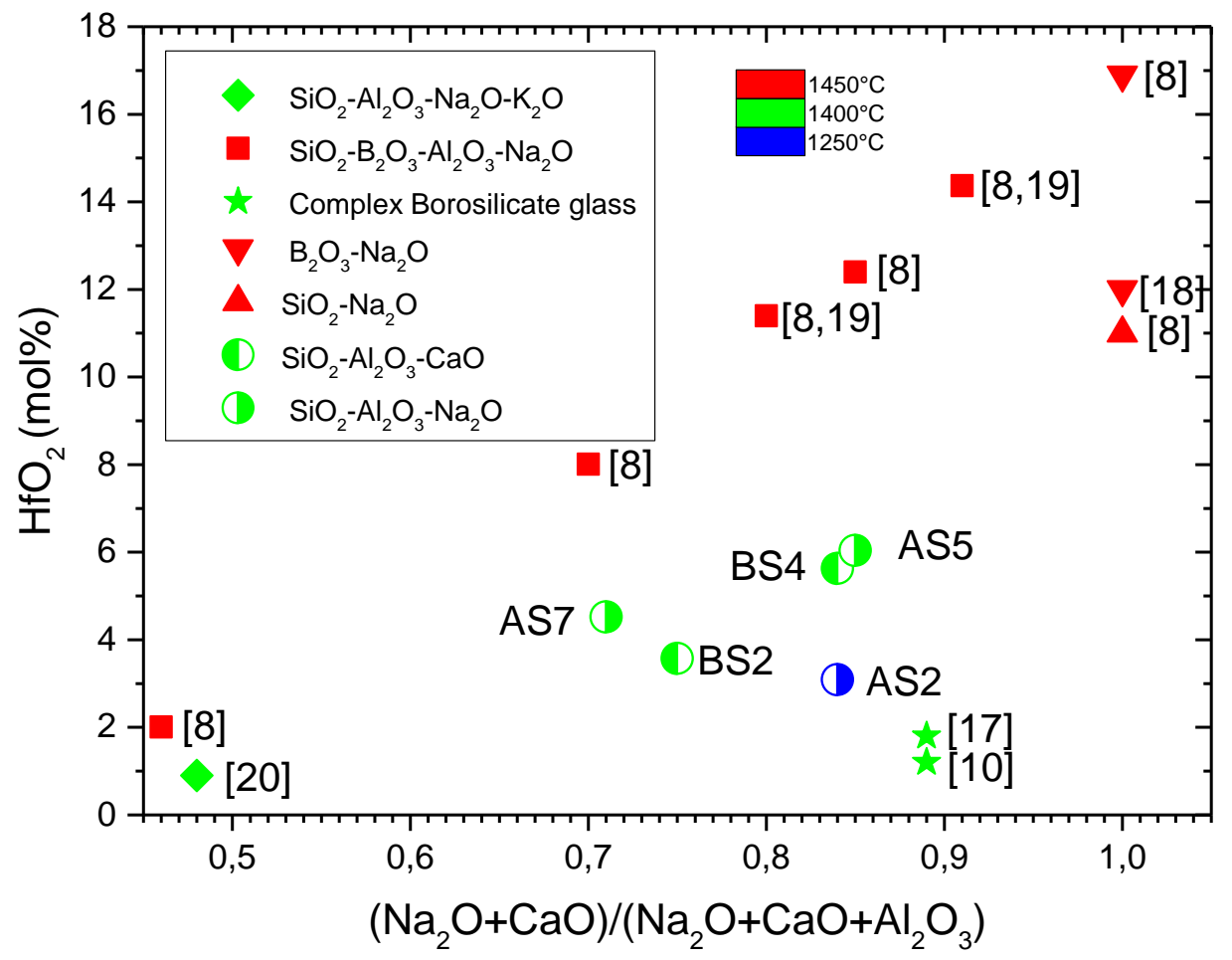

Figure 12. Comparison of hafnium solubility in $A$ and $B$ glasses to hafnium solubility in several types of glasses from the literature. $\mathrm{HfO}_{2}$ concentration in mole percent is plotted as the function of the $\mathrm{M}^{*}$ ratio $\left(\mathrm{CaO}+\mathrm{Na}_{2} \mathrm{O}\right) /\left(\mathrm{CaO}+\mathrm{Na}_{2} \mathrm{O}+\mathrm{Al}_{2} \mathrm{O}_{3}\right)$ in molar content.

\subsection{Hafnium crystallization}

The morphology of hafnium silicate crystals suggests that these crystals are quickly formed and quite stable in the melt. The $\mathrm{HfO}_{2}$ crystals seem to grow following an Oswald ripening process [29, 30]. Nanometric $\mathrm{HfO}_{2}$ are not observed in the melt but as inclusions in the hafnium silicate crystals indicating that they might have been poikilitically enclosed in the silicates before their growth.

Dendritic or needle crystals could be quench crystals [31]. As the temperature decreases during quenching, the glass melt becomes supersaturated with hafnium leading to a quick overgrowth of hafnium crystal along one or two preferential axes. However, those crystals are concentrated at the glass/crucible interface which is not logical for quench crystals. These crystals should also be observed in the core of the glass sample where the cooling rate is ordinarily the lowest. Moreover, the crown-shaped crystals do not really look like quench crystals. All this suggests that these crystals result from a reaction between the glass and the $\mathrm{C}-\mathrm{SiC}$ crucible. The mullite binder might react with the glass melt in this area as shown by the glass enrichment in $\mathrm{Al}_{2} \mathrm{O}_{3}$ and $\mathrm{SiO}_{2}$ and depletion in other elements $(\mathrm{CaO}$ and $\mathrm{HfO}_{2}$ ). All these crystallization mechanisms are not fully understood in this work and need to be deepened.

The $\mathrm{Na}_{2} \mathrm{HfSi}_{2} \mathrm{O}_{7}$ crystalline phase has been detected for the first time. The existence of this phase is confirmed by its synthesis and its crystal structure determination. The Rietveld refinement of the XRD pattern containing this crystalline phase allows us to quantify it. The isomorphic character between the $\mathrm{Na}_{2} \mathrm{HfSi}_{2} \mathrm{O}_{7}$ and the parakeldyshite $\mathrm{Na}_{2} \mathrm{ZrSi}_{2} \mathrm{O}_{7}$ can be explained by close ionic radii for $\mathrm{Hf}$ and $\mathrm{Zr}$ for the same coordination number [32]. All detail 
about the structure of $\mathrm{Na}_{2} \mathrm{HfSi}_{2} \mathrm{O}_{7}$ are currently submitted and reviewed for a formal data deposition into XRD databases.

\section{Conclusion}

In this study, an experimental protocol has been developed in order to measure the hafnium solubility in aluminosilicate glass melted in both oxidizing and reducing conditions. Hf-doped glass elaboration conditions have been optimized to limit the $\mathrm{HfO}_{2}$ sedimentation and to approach equilibrium. Contrary to the conditional solubility, the saturation solubility readily allows to determine a thermodynamic solubility. As hafnium speciation remains the same in the glass matrix $\left(\mathrm{Hf}^{\mathrm{f}}\right)$, its solubility is not affected by the redox conditions. In peralkaline glasses (with molar content $\left.\left(\mathrm{Na}_{2} \mathrm{O}+\mathrm{CaO}\right)>\mathrm{Al}_{2} \mathrm{O}_{3}\right)$, the $\mathrm{HfO}_{2}$ solubility limit is positively correlated with the melting temperature and the excess of network modifier cation $\left(\mathrm{Na}_{2} \mathrm{O}\right.$ and $\mathrm{CaO}$ ) relatively to $\mathrm{Al}_{2} \mathrm{O}_{3}$. The hafnium solubility also seems to be slightly impacted by the nature of these cations. These results are in agreement with previous studies of +4 cations in borosilicate or aluminosilicate glasses. The hafnium solubility appears to be higher in borosilicate glasses than in aluminosilicate glasses for a similar excess of alkalis or alkaline earths.

Above the hafnium solubility limit, formations of $\mathrm{HfO}_{2}, \mathrm{HfSiO}_{4}, \mathrm{Ca}_{2} \mathrm{HfSi}_{4} \mathrm{O}_{12}, \mathrm{Na}_{4} \mathrm{Hf}_{2}\left(\mathrm{SiO}_{4}\right)_{3}$ and $\mathrm{Na}_{2} \mathrm{HfSi}_{2} \mathrm{O}_{7}$ crystals have been observed in those glasses. The glass composition and potentially the redox conditions change the nature of the Hf-bearing crystals. The existence of the $\mathrm{Na}_{2} \mathrm{HfSi}_{2} \mathrm{O}_{7}$ crystalline phase has been evidenced in Na-rich aluminosilicate melts and for temperatures close to $1250^{\circ} \mathrm{C}$. The Rietveld refinement of $\mathrm{Na}_{2} \mathrm{HfSi}_{2} \mathrm{O}_{7}$ has been successfully performed. The $\mathrm{Na}_{2} \mathrm{HfSi}_{2} \mathrm{O}_{7}$ phase structure appears to be very similar than the parakeldyshite $\mathrm{Na}_{2} \mathrm{ZrSi}_{2} \mathrm{O}_{7}$ phase structure.

The optimization of $\mathrm{Hf}$-doped glass elaboration conditions will be further used for the preparation of U-doped glasses. Indeed, the uranium incorporation in the glass melt faces to the same sedimentation issues [6]. Besides, $\mathrm{UO}_{2}$ solubility is also likely to be related to the excess of alkalis [4]. The uranium behavior however remains more complex than the hafnium one. The chemistry of uranium in glass melt is ruled by the equilibria of $U^{\mathrm{VI}}-U^{\mathrm{V}}-U^{\mathrm{IV}}[7]$. The $\mathrm{UO}_{2}$ solubility in glass melt as the function of the oxygen fugacity $\left(\mathrm{fO}_{2}\right)$ is the subject of ongoing studies and those data will be compared to the $\mathrm{HfO}_{2}$ solubility.

\section{Acknowlegdments}

The authors gratefully acknowledge B. Pénélon for performing viscosity measurements. This work was financially supported by CEA, AREVA and ANDRA.

\section{References}

[1] M. Cable, Kinetics of volatilization of sodium borate melts, in: L.D. Pye, V.D. Fréchette, N.J. Kreidl (Eds.) Borate Glasses: Structure, Properties, Applications, Springer US, Boston, MA, 1978, pp. 399-411.

[2] J.N. Cachia, X. Deschanels, C. Den Auwer, O. Pinet, J. Phalippou, C. Hennig, A. Scheinost, Enhancing cerium and plutonium solubility by reduction in borosilicate glass, J. Nucl. Mater., 352 (2006) 182-189.

[3] H.D. Schreiber, G.B. Balazs, The chemistry of uranium in borosilicate glasses .1. Simple base compositions relevant to the immobilization of nuclear waste, Phys. Chem. Glasses, 23 (1982) 139-146. 
[4] F. Domine, B. Velde, Preliminary investigation of the processes governing the solubility of uranium in silicate melts, Bulletin De Mineralogie, 108 (1985) 755-765.

[5] D.J. Lam, B.W. Veal, A.P. Paulikas, X-ray photoemission spectroscopy (xps) study of uranium, neptunium, and plutonium oxides in silicate-based glasses, Acs Symposium Series, 216 (1983) 145-154.

[6] Y.I. Matyunin, S.V. Yudintsev, Immobilization of U3O8 in borosilicate glass in an induction melter with a cold crucible, Atom. Energy, 84 (1998) 173-178.

[7] H.D. Schreiber, The chemistry of uranium in glass-forming aluminosilicate melts, Journal of the Less-Common Metals, 91 (1983) 129-147.

[8] L.L. Davis, J.G. Darab, M. Qian, D. Zhao, C.S. Palenik, H. Li, D.M. Strachan, L. Li, Hafnium in peralkaline and peraluminous boro-aluminosilicate glass and glass sub-components: a solubility study, J. Non-Cryst. Solids, 328 (2003) 102-122.

[9] K.M. Fox, J.C. Marra, T.B. Edwards, E.N. Hoffman, C.L. Crawford, Plutonium feed impurity testing in lanthanide borosilicate (LaBS) glass, in: W.E. Lee, J.W. Roberts, N.C. Hyatt, R.W. Grimes (Eds.) Scientific Basis for Nuclear Waste Management Xxxi, Materials Research Society, Warrendale, 2008, pp. 397-404.

[10] C. Lopez, X. Deschanels, J.M. Bart, J.M. Boubals, C. Den Auwer, E. Simoni, Solubility of actinide surrogates in nuclear glasses, J. Nucl. Mater., 312 (2003) 76-80.

[11] Y.H. Zhang, A. Navrotsky, H. Li, L.Y. Li, L.L. Davis, D.M. Strachan, Energetics of dissolution of Gd2O3 and HfO2 in sodium alumino-borosilicate glasses, J. Non-Cryst. Solids, 296 (2001) 93-101.

[12] X. Deschanels, S. Peuget, J.N. Cachia, T. Charpentier, Plutonium solubility and self-irradiation effects in borosilicate glass, Prog. Nucl. Energy, 49 (2007) 623-634.

[13] H. Khedim, R. Podor, P.J. Panteix, C. Rapin, M. Vilasi, Solubility of chromium oxide in binary soda-silicate melts, J. Non-Cryst. Solids, 356 (2010) 2734-2741.

[14] E.B. Watson, Zircon saturation in felsic liquids - experimental results and applications to trace-element geochemistry, Contrib. Mineral. Petrol., 70 (1979) 407-419.

[15] M.P. Dickenson, P.C. Hess, Redox equilibria and the structural role of iron in alumino-silicate melts, Contrib. Mineral. Petrol., 78 (1981) 352-357.

[16] H. Khedim, S. Abdelouhab, R. Podor, C. Rapin, M. Vilasi, P.J. Panteix, M. Toplis, F. Faure, Kinetic and equilibrium factors affecting saturation of chromium oxide in soda-silicate melts, J. Non-Cryst. Solids, 357 (2011) $31-42$.

[17] J.N. Cachia, Solubilité d'éléments aux degrés d'oxydation III et IV dans les verres de borosilicate, in, PhD thesis, Université de Monpellier II, 2005, pp. 239.

[18] M.A. Res, J. Bednarik, S. Hart, H. Schonberger, Transformation of Na2O-HfO2-B2O3 glass into a material having interconnected pores, J. Mater. Sci., 21 (1986) 2169-2174.

[19] X. Feng, H. Li, L.L. Davis, L. Li, J.G. Darab, M.J. Schweiger, J.D. Vienna, B.C. Bunker, P.G. Allen, J.J. Bucher, Distribution and solubility of radionuclides in waste forms for disposition of plutonium and spent nuclear fuels: Preliminary results, CERAMIC TRANSACTIONS, 93 (1999) 409-420.

[20] A.J. Ellison, P.C. Hess, Solution behavior of +4 cations in high silica melts - petrologic and geochemical implications, Contrib. Mineral. Petrol., 94 (1986) 343-351.

[21] C. Frontera, J. Rodriguez-Carvajal, FULLPROF as a new tool for flipping ratio analysis, Physica B, 335 (2003) 219-222.

[22] J. Puig, C. Hanotin, M. Neyret, P. Marchal, High temperature rheological study of borosilicate glasses containing platinum group metal particles by means of a mixer-type rheometer, J. Nucl. Mater., 469 (2016) 112 119.

[23] M.I. Ojovan, Viscosity and glass transition in amorphous oxides, Adv. Condens. Matter Phys., (2008) 23.

[24] J.D. Vienna, D.L. Alexander, H. Li, M.J. Schweiger, D.K. Peeler, P.N.N. Laboratory, U.S.D.o. Energy, Plutonium Dioxide Dissolution in Glass, Pacific Northwest National Laboratory, 1996.

[25] L.S. Walter, Giutroni.Je, Vapor fractionation of silicate melts at high temperatures and atmospheric pressures, Sol. Energy, 11 (1967) 163-169.

[26] P. Ferreira, A. Ferreira, J. Rocha, M.R. Soares, Synthesis and structural characterization of zirconium silicates, Chem. Mat., 13 (2001) 355-363.

[27] N. Massoni, P. Chevreux, Crystal structure of Na2HfSi2O7, Acta Crystallographica, Section D.

[28] C. Lopez, Solubilité des actinides et de leurs simulants dans les verres nucléaires : limites d'incorporation et compréhension des mécanismes, in, PhD thesis, Université de Paris XI,Orsay, 2003, pp. 239.

[29] P.W. Voorhees, The theory of Ostwald ripening, Journal of Statistical Physics, 38 (1985) 231-252.

[30] J.H. Yao, K.R. Elder, H. Guo, M. Grant, Theory and simulation of Ostwald ripening, Phys. Rev. B, 47 (1993) 14110-14125.

[31] Y. Chen, Y.X. Zhang, Olivine dissolution in basaltic melt, Geochimica Et Cosmochimica Acta, 72 (2008) 4756-4777.

[32] R.D. Shannon, Revised effective ionic radii and systematic studies of interatomic distances in halides and chalcogenides, Acta Crystallogr. A, Cryst. Phys. Diffr. Theor. Gen. Crystallogr., A32 (1976) 751-767. 